Article

\title{
Prosecuting Crimes against Humanity and Genocide at the International Crimes Tribunal Bangladesh: An Approach to International Criminal Law Standards
}

\author{
Maruf Billah
}

check for

updates

Citation: Billah, Maruf. 2021.

Prosecuting Crimes against

Humanity and Genocide at the

International Crimes Tribunal

Bangladesh: An Approach to

International Criminal Law

Standards. Laws 10: 82. https:/

/doi.org/10.3390/laws10040082

Received: 30 September 2021

Accepted: 27 October 2021

Published: 31 October 2021

Publisher's Note: MDPI stays neutral with regard to jurisdictional claims in published maps and institutional affiliations.

Copyright: (C) 2021 by the author. Licensee MDPI, Basel, Switzerland. This article is an open access article distributed under the terms and conditions of the Creative Commons Attribution (CC BY) license (https:/ / creativecommons.org/licenses/by/ $4.0 /)$.
Department of International Cooperation Studies, Graduate School of International Development, Nagoya University, Furo-cho, Chikusa-ku, Nagoya 464-8601, Japan; marufiium@gmail.com

\begin{abstract}
Bangladesh is recently prosecuting and punishing the perpetrators of crimes against humanity and genocide committed in the Liberation War of 1971 via a domestically operated tribunal, namely the International Crimes Tribunal Bangladesh (ICTB). Though the Tribunal is preceded under municipal law, its material jurisdiction, i.e., crimes against humanity and genocide, originated from international criminal law. Therefore, this study examines several legal obligations of the ICTB in defining crimes against humanity and genocide as the core international crimes. First, I discuss several legal flaws of the Tribunal by defining crimes against humanity and genocide under the ICTB Statute and jurisprudence. Second, I scrutinize the legal status of international (treaty and customary) laws in Bangladesh's legal system. Third, by applying international criminal law standards, I focus on the idea that it is one of the obligations of Bangladesh to apply international criminal law definitions of genocide under the treaty obligation as the contracting parties to Genocide Convention 1948, and the ICC Statute 1998. Fourthly, I also discuss whether Bangladesh has any obligation to apply customary international law definition of crimes against humanity because crimes against humanity are considered jus cogens offenses in general international law, from which no derogation is permitted. Lastly, I conclude that Bangladesh Tribunal failed to fulfill its legal obligation to define international crimes under the treaty and customary laws and forward a way to be implemented to improve the legislative system of Bangladesh and harmonize it with international legislation.
\end{abstract}

Keywords: Bangladesh Tribunal; prosecution of international crimes; treaty and customary law obligations to define international crimes

\section{Introduction}

The ICTB was established in 2010 and is currently operating by the current government of Bangladesh to prosecute and punish the perpetrators of crimes against humanity and genocide committed in the Bangladesh Liberation War of 1971. The legal character of the ICTB is domestic, and it is functioning entirely in the domestic setting for several reasons. First, the founding instrument of the ICTB is categorized purely domestic as no treaty was concluded between the government of Bangladesh and the United Nations (UN) or its agencies and no UN Resolution on the issue of creating an accountability mechanism on violation of human rights in the Liberation War of Bangladesh was passed. Such international instruments were applied to form ad hoc criminal tribunals- the International Criminal Tribunal for the Former Yugoslavia (ICTY) and the International Criminal Tribunal 
for Rwanda (ICTR). ${ }^{1}$ Similarly, the hybrid criminal tribunals, i.e., Special Court for Sierra Leone (SCSL), Extraordinary Chambers in the Courts of Cambodia (ECCC), and Special Panels for Serious Crimes (SPSC) in East Timor were also created by the conclusion of treaties between the UN and specific countries. ${ }^{2}$ Second, the organization of the court is solely domestic, due to no participation of international judges, members, and prosecutors, in the adjudicating mechanism of this tribunal, which is also dissimilar to the ad hoc and hybrid criminal tribunals of the SCSL, ECCC, and SPSC in East Timor. Therefore, it is inferred that the ICTB is working under the Bangladeshi legal system as a local court aimed to prosecute and punish the perpetrators of international crimes committed in the Liberation War in 1971. In comparison to international criminal courts and tribunals, the ICTB is purely domestic because of the non-involvement of Bangladeshi authority with an international agreement with the UN or any other international institutions such as the International Criminal Court (ICC) and non-participation of international judges and prosecutors in the operation of the Tribunal.

As a domestic judicial mechanism, the Tribunal in question is obliged to apply the International Crimes Tribunal (ICT) Act 1973 and its (Amendment) Act 2009. Since the ICT Act 1973 and (Amendment) Act 2009 are considered to be the principal legal instruments of the Tribunal, it consists of a series of legal provisions on the definitions of the crimes against humanity and genocide (International Crimes Tribunal Act, Section 3 (2) (a) and (c) 1973). However, such definitions of crimes against humanity and genocide were not reflected by the treaty and customary international laws requirements either in 1971-when these international crimes were committed or in 2010, when the ICTB started to prosecute and punish the offenders of these crimes. To date, in prosecuting crimes against humanity as international crimes, no multilateral treaty is promulgated by the UN's International Law Commission (ILC) to ratify it by the States. Hence, the latest customary international law definition is crucial for any criminal tribunal prosecuting and punishing crimes against humanity to prove the international criminality of such crimes, which is missing in the ICTB. Then, in prosecuting genocide as a transnational crime, the Convention on the Prevention and Punishment of the Crime of Genocide 1948 (hereinafter the Genocide Convention 1948) emerged as the multilateral treaty concluded between the community of States to prevent and punish the offense of genocide. Like other contracting parties to the Genocide Convention 1948, Bangladesh also ratified the Convention in $1998^{3}$ in punishing the offenders of genocide in the domestic setting.

Similarly, more recently, Bangladesh has ratified the Rome Statute of the International Criminal Court (hereinafter the ICC Statute) $1998^{4}$ to prosecute and punish the perpetrators of genocide through the ICTB. Nevertheless, to date, there is no initiative taken by the Government of Bangladesh to implement these provisions of international law on genocide, by legislating national law in the Bangladeshi legal system, to criminalize offense of

1 See, United Nations Security Council Resolution 808 (1993), [on the Establishment of International Tribunal for the Prosecution of Persons Responsible for the Serious Crimes Committed in Violation of International Humanitarian Law in the Territory of Former Yugoslavia.] UN Doc. S/25704, https:/ / www.icty.org/x/file/Legal\%20Library/Statute/statute_re808_1993_en.pdf (accessed on 25 September 2021); United Nations Security Council resolution 955 (1994) [on establishment of an International Tribunal for Rwanda and adoption of the Statute of the Tribunal, having received the request of the Government of Rwanda (S/1994/1115), to establish an international tribunal for the sole purpose of prosecuting persons responsible for genocide and other serious violations of international law committed in the territory of Rwanda.] UN Doc. S/RES/955 (1994), https: / / digitallibrary.un.org/record/198038?ln=en (accessed on 20 August 2021).

2 See for example, Agreement between the United Nations and the Royal Government of Cambodia on The Establishment of Extraordinary Chambers in the Courts of Cambodia for the Prosecution of Crimes Committed during the Period of Democratic Kampuchea, 2004, UN Doc. (NS/RKM/1004/006); United Nations Security Council Resolution on the Establishment of a Special Court for Sierra Leone, 14 August 2000. UN Doc. S/RES/1315 (2000). https: / / digitallibrary.un.org/record/420605?ln=en (accessed on 20 September 2021); United Nations Transitional Administration in East Timor on the Establishment of Panels with Exclusive Jurisdiction Over Serious Criminal Offences, 2000, UN Doc. UNTAET/Reg/2000/15, https:/ / www.legal-tools.org/doc/c082f8/pdf/ (accessed on 29 October 2021).

3 Bangladesh has ratified Genocide Convention 1948 on 5 October 1998, see ICRC, https://ihl-databases.icrc.org/applic/ihl/ihl.nsf/States.xsp?xp_ viewStates=XPages_NORMStatesParties\&xp_treatySelected=357 (accessed on 25 October 2021). (deleted due to repetition).

4 Bangladesh has ratified the ICC Statute 1998 on 23 March 2010. See International Criminal Court, https://www.icccpi.int/Pages/item.aspx?name= bangladesh+ratifies+the+rome+statute+of+the+international+criminal+court\&ln=en (accessed on 24 October 2021). 
genocide under Article $2^{5}$ of the Genocide Convention 1948 and Article 6 (the same as the Article 2 of the 1948 Genocide Convention) of the ICC Statute 1998. Though the ICT Act 1973 adopted the definition of the offense of genocide as an international crime, it did not replicate the exact definition of genocide enumerated in the Genocide Convention 1948 and ICC Statute 1998 by adding 'political group' as one of the protected groups (Section 3 (2) (c) of the ICT Act 1973). The internationally recognized definition does not cover the inclusion of political groups and, therefore, does not reflect prevailing customary international law, neither in 1971, at the time when the crimes were committed, nor in 2010 when the ICTB started its operation (O'Keefe 2015, p. 70). Until today, no 'concrete' legislative procedure can be seen in the stage of implantation of the provisions of the international law on genocide in the national law of Bangladesh. Therefore, any types of 'concrete' measures as the form of Proposals are indispensable to implement the provisions of international law on genocide by the Bangladesh government to adhere to the entire spirit of the Genocide Convention 1948 and the ICC Statute at the national level. As the result of this research, several types of 'concrete' measures will be outlined in the Proposals section (of the current article), one of the ways to be implemented by the government of Bangladesh in order to improve the domestic legislative system and harmonize it with international legislations, i.e., the Genocide Convention 1948, and the ICC Statute 1998.

Correspondingly, though the Tribunal considers the ICT Act 1973 as the principal legislation, sometimes the Tribunal also applies some other international criminal law and jurisprudence in settling the cases. ${ }^{6}$ Undoubtedly, without any domestic legislation allowing international law invocation in the ICTB, the ICTB applied international criminal law jurisprudence. Simultaneously, the Tribunal in question is silent on the explicit invocation of international criminal law in defining crimes against humanity and genocide to prove individual criminality against the alleged perpetrators. Hence, it is one of the possible legal hypotheses to infer whether the ICTB is obliged to apply international criminal law to settle any disputes in the Tribunal, particularly to define international crimes. Furthermore, as a state party to several international treaties, it is indispensable to analyze whether Bangladesh is obliged to apply and prosecute international crimes as per the requirements of the treaties. Suppose the answer to these legal questions obliges the ICTB to apply international criminal law definitions of crimes against humanity and genocide. In that case, another question comes forward whether the Tribunal has any legal duty to adhere to the legal definitions of these crimes as per definitions under the treaty and customary law in settling any cases in the ICTB. Then, is it a legal competence or obligation conferred on Bangladesh that the Tribunal in question needs to refer to international law and jurisprudence? These issues are discussed in detail throughout this article.

Whether the previous literature discusses the above research questions and problems of the current study is also relevant to analyze briefly here. One of the early legal analyses endeavored by Linton in 2010, immediately after establishing the ICTB, examined several discrepancies of the ICT Act 1973, in line with the domestic and international criminal

5 Article 2 of the Genocide Convention 1948 says, "[i]n the present Convention, genocide means any of the following acts committed with intent to destroy, in whole or in part, a national, ethnical, racial or religious group, as such: (a) Killing members of the group; (b) Causing serious bodily or mental harm to members of the group; (c) Deliberately inflicting on the group conditions of life calculated to bring about its physical destruction in whole or in part; (d) Imposing measures intended to prevent births within the group; (e) Forcibly transferring children of the group to another group."

6 The ICTB has referred to ICTY, ICTR, and SCSL Statutes, for allowing retroactive prosecution of international crimes, see for example, in Chief Prosecutor v. Abul Kalam Azad, ICTB Case No. 05 of 2012, Judgment, 21 January 2013, para. 14; Chief Prosecutor v. Delowar Hossain Sayeedi, ICTB Case No 01 of 2011, Judgment, 28 February 2013, para. 52; Chief Prosecutor v. Abdul Quader Molla, ICTB Case No. 02 of 2013, Judgment, 5 February 2013, para. 3; Chief Prosecutor v. Muhammad Kamaruzzaman, ICTB Case No. 03 of 2012, Judgment, 9 May 2013, para. 3; Chief Prosecutor v. Salauddin Quader Chowdhury, ICTB Case No. 02 of 2011, Judgment, 1 October 2013, para. 64; Chief Prosecutor v. Ali Ahsan Muhammad Mujahid, ICTB Case No. 04 of 2012, Judgment, 17 July 2013, para. 3, and Chief Prosecutor v. Professor Golam Azam, ICTB Case No. 06 of 2011, Judgment, 15 July, 2013, para. 55. Then the Tribunal heavily relied on the ICTY Blaskic's case, to prove the material jurisdiction in various cases, for example, Chief Prosecutor v. Abul Kalam Azad, ICTB Case No. 05 of 2012, Judgment, 21 January 2013, para. 313; Chief Prosecutor v. Kamaruzzaman, ICTB Case No. 03 of 2012 , Judgment, 9 May 2013, para. 511; Chief Prosecutor v. Abdul Quader Molla, ICTB Case No. 02 of 2013, Judgment, 5 February 2013, para. 376. The Tribunal also referred to ICTY Blaskic's case to prove 'persecution' as crimes against humanity, see for example, Chief Prosecutor v. Ali Ahsan Muhammad Mujahid, ICTB Case No. 04 of 2012, Judgment, 17 July 2013, paras. 564, 565. 
law standards (Linton 2010, p. 206). She mainly looked at the Tribunal according to the customary international law requirements in 1971, the material times of the commission of the crimes, and 2010, the prosecuting time of these crimes (ibid., pp. 231-49). Based on the theoretical analysis, her study contributed that "[a]ny trial process, especially of such a charged matter as the crimes of the [Bangladesh] liberation war, must meet international standards to have any legitimacy, honor the victims and provide some kind of redress to survivors (ibid., p. 191)." Similarly, some other researchers have conducted a series of analyses that critically evaluate the provisions in the ICT Act 1973 in light of the international war crimes laws. They examined many flaws such as non-compliance with international standards, especially the Tribunal's material jurisdiction. While some legal studies concluded that the international crimes that are being tried and punished based on the ICT Act repeatedly fall short of customary law standard, some academic debates even conducted an in-depth analysis by claiming that the domestic judicial process established by the ICT Act is a case of "complementarity went bad." ${ }^{7}$ However, the theoretical legal studies conducted by Linton and other researchers fail in analyzing customary law requirements of crimes against humanity and genocide in 1971 and 2010, which are indispensable to differentiate these two crimes from domestic crimes.

Furthermore, no legal obligations of the Bangladesh Tribunal to the treaty and customary law to define these two international crimes (genocide and crimes against humanity) are discussed by them. After Linton's theoretical legal work on the ICT Act 1973, another detailed study was conducted by Robertson QC on the ICTB, focusing on the academic examination of the Tribunal in question. He also partially analyzes the jurisprudence of the ICTB. Hence, unlike Linton, his legal analysis contributed to the requirement of indicting crimes against humanity as ex post facto crimes (requirements of widespread and systematic attack against any civilian population) by referring to some cases of the ICTB (Robertson 2015, pp. 94-99). Lastly, in recent times, another detailed legal study was conducted by Islam on the ICTB by referring to various jurisprudence of the Tribunal that analyzes legal features of crimes against humanity as international offenses. He considered the description of crimes against humanity in the ICT Act 1973 as similar to the same crimes identified in the IMT Nuremberg Charter by saying that,

"There is a strong similarity between the constituent elements of crimes against humanity in the 1973 Act and the Nuremberg Charter, which may be attributable to the fact that there was no formal legal instrument containing the definitional elements of crimes against humanity at the time of the enactment of the 1973 Act other than the Nuremberg Charter." (Islam 2019, p. 71)

Furthermore, his research explores the recent development of treaty and customary law requirements of 'widespread' and 'systematic' attacks against any civilian population to define crimes against humanity. However, he concludes that

"[F]or constituting the offense of crimes against humanity, the element 'the attack must be widespread and systematic against civilian population' was not at all necessary or mandatory if it was found that the crime was committed in the context of the Bangladesh liberation war in 1971." (ibid., p. 76)

In the ICTB, all of the offenders were convicted for the offense of crimes against humanity. Nevertheless, his study fails to apply international criminal law requirements in the ICTB cases under the treaty and customary international laws in 1971 and 2010 to define

\footnotetext{
7 See for examples, Md. Abdul Jalil, "War Crimes Tribunals in Bangladesh: A Socio-Political and Legal Impact Analysis", Journal of Sociloligical Research 3, no. 2 (2012): 333; Surabhi Chopra, "The International Crimes Tribunal in Bangladesh: Silencing fair comment", Journal of Genocide Research 17, no. 2 (2015): 212; Jhuma Sen, "The Trial of Errors in Bangladesh: The International Crimes (Tribunals) Act and the 1971 War Crime Trial". Harvard Asia Quarterly, (2012): 34-37; Abdus Samad, "The International Crimes Tribunal in Bangladesh and International Law", Criminal Law Forum 27, (2016): 257-290; See also, Abdur Razzaq, "The Tribunals in Bangladesh: Falling Short of International Standards", in Kirsten Sellars (ed.), Trials for International Crimes in Asia (Cambridge: Cambridge University Press, 2016), 341-359; Beth Van Schaack, "The Bangladesh International Crimes Tribunal: Complementarity Gone Bad", in IntLawGrrls (voices of international law, policy, and practice), 8 October 2014, available at https://ilg2.org/2014/10/08/the-bangladesh-international-crimes-tribunal-bict-complementarity-gone-bad/ (accessed on 29 September 2021).
} 
crimes against humanity and genocide (ibid., pp. 22-23). Similarly, studies conducted by Robertson QC and Islam do not explain Bangladesh's domestic legal obligation in applying international criminal law standards in the case of any legal uncertainties in prosecuting crimes against humanity and genocide as international crimes. It is crucial to outline Bangladesh's legal duties to apply treaty and customary international laws. As a contracting party to the 1948 Genocide Convention and the ICC Statute 1998, there must be a legal duty imposed on Bangladesh to apply international criminal law requirements of genocide. Then, another legal obligation is prescribed on Bangladesh to prosecute and punish the culprits of crimes against humanity, which are considered jus cogens crimes in international law. Such crimes need to be defined as per international customary law in the absence of any treaty definition. At the same time, these pressing issues missed out in the legal study conducted by both of them.

Based on the above research gaps, this study aims to achieve the following research objectives. First, this study purposes of examining several legal flaws of the Tribunal in defining crimes against humanity and genocide as the core international crimes because the Tribunal is prosecuting crimes against humanity and genocide "committed in violation of customary international law and Bangladesh considers that the State has an obligation to remedy serious human rights violations (Chief Prosecutor v. Abdul Quader Molla, para. 45)." The Tribunal is prosecuting crimes against humanity and genocide committed almost 50 years ago, while such crimes had attained the status of customary international law. ${ }^{8}$ Second, the study scrutinizes the legal status of international (treaty and customary) laws in Bangladesh's legal system. Third, this research intends to analyze that it is one of the obligations of Bangladesh to apply international criminal law definitions of crimes against humanity and genocide under the treaty obligations as the contracting parties to Genocide Convention 1948 and the ICC Statute 1998. Fourthly, this study objects to examine that Bangladesh has a legal obligation to apply customary international law definitions of crimes against humanity and genocide because both of these crimes are prohibited as jus cogens crimes. According to the Vienna Convention on the Law of Treaties (VCLT), "jus cogens a peremptory norm of general international law is a norm accepted and recognized by the international community of States as a whole as a norm from which no derogation is permitted and which can be modified only by a subsequent norm of general international law with the same character (VCLT, Art. 53)." Later, the jus cogens nature of crimes against humanity and genocide are defined by the ILC. ${ }^{9}$ Furthermore, sufficient legal basis exists to conclude that all these crimes are part of jus cogens (peremptory norm of general international law) due to widespread practices of international tribunals to prosecute

8 For example, genocide is also defined as an international crime in the Rome Statute of the International Criminal Court (ICC), Article 6, the Statute of the International Criminal Tribunal for Rwanda (ICTR), Article 2(2), and the Statute of the International Criminal Tribunal for the former Yugoslavia (ICTY), Article 4(2); The International Residual Mechanism for Criminal Tribunals, continuing the ICTY and ICTR's jurisdiction, and the Law on the Establishment of the Extraordinary Chambers in the Courts of Cambodia, Article (4), hybrid tribunals also have criminalized genocide such as, ECCC Statute Article 4. Many States have also criminalized genocide in their domestic law such as Rwanda. Similarly, crimes against humanity also criminalized in the IMT Charter Article 6(c), also defined as an international crime in the Rome Statute of the International Criminal Court (ICC), Article 7, the Statute of the International Criminal Tribunal for Rwanda (ICTR), Article 3, and the Statute of the International Criminal Tribunal for the former Yugoslavia (ICTY), Article 5; The International Residual Mechanism for Criminal Tribunals, continuing the ICTY and ICTR's jurisdiction, and the Law on the Establishment of the Extraordinary Chambers in the Courts of Cambodia, Article 5, hybrid tribunals also have criminalized genocide such as, ECCC Statute Article 5.

9 According to the ILC, the most frequently cited candidates for jus cogens status include: (a) the prohibition of aggressive use of force; (b) the right to self-defense; (c) the prohibition of genocide; (d) the prohibition of torture; (e) crimes against humanity; (f) the prohibition of slavery and slave trade; (g) the prohibition of piracy; (h) the prohibition of racial discrimination and apartheid, and (i) the prohibition of hostilities directed at a civilian population ('basic rules of international humanitarian law'), see ILC, Report of the Study Group on Fragmentation of International Law: Difficulties arising from the Diversification and Expansion of International Law (13 April 2006) UN Doc A/CN.4/L.682, para 374; ILC, Official Records of the General Assembly, Fifth-sixth Session (5 May-6 June and 7 July-8 August 2003) UN Doc A/56/10, 283-84; 'Commentary to Article 26 ' in 'Draft articles on the Responsibility of International Organizations with Commentaries' 2 Year Book of International Law Commission (2011). 
and punish them through the effective mechanism. ${ }^{10}$ Lastly, the study concludes that Bangladesh Tribunal failed to fulfill its legal obligation to define international crimes under the treaty and customary laws and forwards Proposals to be implemented to improve the legislative system of Bangladesh and harmonize it with international criminal legislation.

Apart from the research objectives, this study is significant as the ICTB is prosecuting and punishing international crimes domestically without the assistance of international institutions such as the UN and the International Criminal Court (ICC). The lawful sources on which the ICTB is founded are crucial indicators of how operative the tribunal is, providing justice to the accused by prosecuting legally defined international crimes and providing some kinds of redress to the victims. Hence, Schabas rightly argues that criminal tribunals cannot prosecute cases involving international crimes that are not explicitly or implicitly defined according to international criminal law (Schabas 2006, p. 123). It is also significant to define the 'core crimes' of a criminal trial since it can mark the lawfulness and efficiency of a tribunal's outcome. In the case of the ICTB, a relevant legal elaboration of the jurisdiction ratione materiae such as crimes against humanity and genocide is legally crucial because it will command the demeanor which is to be forbidden and how it is characterized as the international or 'serious' crime that differs from a 'regular' crime in municipal law. For instance, the offense of crimes against humanity needs to be separated from the ordinary crimes of murder, extermination, torture, etc., by honoring the specific elements of such crimes under international customary law at the appropriate time. A similar proposition is also identical in prosecuting genocide, though the ICTB applies the elements of the definition of genocide as recognized under international law. If the Tribunal has broadened the definition of genocide by the addition of 'political group' as one of the protected groups, which was omitted in the 1948 Genocide Convention and ICC Statute 1998, then the real meaning of genocide will be questioned and is somewhat confusing given that the groups protected under the Convention are targeted because of their specific characteristics. As a result, the whole judicial proceeding might be questioned in achieving criminal justice.

It is also significant to evaluate that the ICTB is a domestic judicial institution, endeavors to end the culture of impunity by trying and punishing the culprits of international crimes and must adhere to the international legal standard in the 'jurisdictional reach' of the Tribunal. One of the factors is that such jurisdictional bases of international crimes originated from international criminal law, which obligates all states to comply with international criminal law. Moreover, it is indispensable to examine that the ICTB is a tribunal concentrated on offenses perpetrated by only one side of the conflict. It may give growth to claims of bias since the tribunal is formed by the support of the victorious party (the Awami League). Therefore, it justifies the legal significances of this study to analyze whether the Tribunal in question sufficiently proves its legal obligation in applying 'international legal standards' to fulfill the requirements of crimes against humanity and genocide as international crimes in a domestic prosecution mechanism. Any failure may abuse the accused parties' rights by the Bangladesh authority and diminish the Tribunal's contribution to international legal scholarship and reconciliation in the international criminal justice system.

Before analyzing any legal errors of the ICTB in defining crimes against humanity and genocide, it is indispensable to discuss the exact legal definitions of these crimes under the ICT Act 1973. To date, the ICTB has settled down 41 individual cases, where all of the accused have been charged only with crimes against humanity and genocide committed in

10 The 1993 International Tribunal for the Former Yugoslavia and the 1994 International Tribunal for Rwanda Statutes include the Statute of the International Tribunal for the Former Yugoslavia, U.N. SCOR, 48th Sess., 3217th mtg., at 1, U.N. Doc. S/RES/827 (1993) and the Statute for the International Tribunal for Rwanda, U.N. SCOR, 49th Sess., 3453rd mtg., at 1, U.N. Doc. S/RES/955 (1994), and address Genocide, Crimes Against Humanity, and War Crimes. The 1996 Code of Crimes includes these three crimes plus Aggression. See Draft Code of Crimes Against Peace and Security of Mankind: Titles and Articles on the Draft Code of Crimes Against Peace and Security of Mankind adopted by the International Law Commission on its Forty-Eighth Session, U.N. GAOR, 51st Sess., U.N. Doc. A/CN.4L.532 (1996), revised by U.N. Doc. A/CN.4L.532/Corr.1 and U.N. Doc. A/CN.41.532/Corr.3. 
the Liberation War of Bangladesh. Hence, the following discussion is crucial for the current study.

\section{Definition of Crimes against Humanity and Genocide in the ICT Act 1973}

\subsection{Crimes against Humanity}

Section 3(2)(a) of the ICT Act 1973 provides jurisdiction over crimes against humanity. The law defines following acts as crimes against humanity,

"[N]amely, murder, extermination, enslavement, deportation, imprisonment, abduction, confinement, torture, rape or other inhumane acts committed against any civilian population or persecutions on political, racial, ethnic or religious grounds, whether or not in violation of the domestic law of the country where perpetrated."

The definition of crimes against humanity in the ICTB is more or less similar to the meaning of the same crimes enshrined in the International Military Tribunal (IMT) Nuremberg Charter Article 6(c). ${ }^{11}$ However, the nexus of 'international armed conflict' as a threshold requirement of crimes against humanity that sufficiently differentiated crimes against humanity at the IMT Nuremberg from ordinary crimes were deliberately left out in the ICTB's 1973 Act. In 1971, under customary international law, crimes against humanity needed to be committed in an international armed conflict, which was argued by the defense in many cases. Nonetheless, the Tribunal repeatedly observed, "[c]rimes against humanity can be committed even in peacetime; the existence of armed conflict is, by definition, not mandatory."12

At the same time, the definition of crimes against humanity also did not reflect the recent development of the customary international law of the same crime as enshrined in the international legal instruments in the late 1990s. The defense in the ICTB challenged the definition of crimes against humanity under the 1973 Act as inadequate and inconsistent with the definition under customary international law presently. In reply to the defense's challenge, the ICTB held that the definition does not require the commission of the constituent offenses to be 'widespread or systematic,' a legal element required in Article 7 of the ICC Statute. ${ }^{13}$

In reply to the defense of the ICTB, both of the above legal arguments- 'international armed conflict' nexus and 'widespread and systematic' attack against any civilian population are not linked with crimes against humanity is not self-evident as forwarded by the Tribunal. It cannot be justified simply as the Tribunal never analyzes the relevant customary law requirements of crimes against humanity in 1971 and today. At the same time, the nexus of 'international armed conflict' was one of the essential elements of crimes against humanity to prove the international criminality of such atrocious acts and to differentiate crimes against humanity from domestic or ordinary crimes. It remained valid until 1992 because, in 1993, the ICTY Statute was adopted by the UN Security Council, which relaxed the strict application of the nexus of 'international armed conflict' in the jurisdiction of

11 Article 6(c) of the IMT Nuremberg Charter 1945 says, "[c]rimes against humanity: namely, murder, extermination, enslave ment, deportation, and other inhumane acts committed against any civilian population, before or during the war, or persecutions on political, racial or religious grounds in execution of or in con nection with any crime within the jurisdiction of the Tribunal, whether or not in violation of the domestic law of the country where perpetrated."

12 See in the ICTB cases of Chief Prosecutor v. Professor Golam Azam, ICTB Case No. 06 of 2011, Judgement, 15 July 2013 , para. 32; also, Chief Prosecutor v. Motiur Rahman Nizami, ICTB Case No. 05 of 2011, Judgment, 19 October 2014, paras. 30, 35, 40; Chief Prosecutor v. Salahuddin Quader Chowdhury, ICTB Case No. 02 of 2011, Judgment, 1 October 2013, para 33.

13 See in the ICTB cases of Chief Prosecutor v. Abul Kalam Azad, ICTB Case No. 05 of 2012, Judgment, 21 January 2013, para 40, 72; Chief Prosecutor v. Abdul Quader Molla, ICTB Case No. 02 of 2013, Judgment, 5 February 2013, paras. 61, 122; Chief Prosecutor v. Muhammad Kamaruzzaman, ICTB Case No. 03 of 2012, Judgment, 9 May 2013, para. 127; Chief Prosecutor v. Md. Abdul Alim, ICTB Case No. 01 of 2012, Judgment, 9 October 2013, para 73; and Chief Prosecutor v. Delowar Hossain Sayeedi, Case No. 01 of 2011, Judgment, 28 February 2013, paras. 18, 28. 
crimes against humanity. ${ }^{14}$ Then, in 1995 the nexus of 'international armed conflict' was totally abolished by replacing 'widespread and systematic' attack against any civilian population as the threshold requirement of crimes against by the ICTY Appeal Judgment in the case of Tadić (Prosecutor v. Tadić, para. 141). Additionally, the definition of crimes against humanity in the ICTB is not similar to the other international and internationalized criminal justice mechanisms such as those in East Timor, Sierra Leone, and Cambodia. These criminal courts clearly defined crimes against humanity as reflected in the time's customary international law. The definition adopted in these mechanisms' statutes mentions that crime against humanity needs to be committed as a 'systematic' or 'widespread' attack directed against a civilian population on national, political, ethnic, racial, or religious grounds. ${ }^{15}$ However, the ICTB persisted unclear about why its definition of crimes against humanity does not reflect the latest customary law status in 1971 and 2010.

\subsection{Genocide}

Genocide is mentioned in Section 3(2)(c) of ICT Act 1973, which states,

"Genocide: meaning and including any of the following acts committed with intent to destroy, in whole or in part, a national, ethnic, racial, religious or political group, such as (i) killing members of the group; (ii) causing serious bodily or mental harm to members of the group; (iii) deliberately inflicting on the group conditions of life calculated to bring about its physical destruction in whole or in part; (iv) imposing measures intended to prevent Births within the group; (v) forcibly transferring children of the group to another group."

The 1973 ICT Act defined the offense of genocide in such a way that is more comparable to the typical definition in the statutes of the ICTY, ICC, International Criminal Tribunal for Rwanda (ICTR) and, Article 2 of the Genocide Convention, ${ }^{16}$ with two significant differences: (1) Political groups are incorporated in the ICT Act 1973, and (2) the phrase 'as such' has become 'such as.' These incorporations contradict the rule promulgated in the 1948 Genocide Convention as well as in the ICC Statute.

Concerning the first problem in the definition of genocide, the inclusion of political groups is not covered by the internationally recognized definition and, therefore, does not reflect prevailing customary international law, neither in 1971, at the time when the crimes were committed nor in 2010 when the Tribunal started its operation ( $\mathrm{O}^{\prime} \mathrm{Keefe} 2015$, p. 70). Relating to the second modification from 'as such' to 'such as' made in the ICT Act 1973 , the definition of the genocide, therefore, reads 'with intent to destroy, in whole or in part, a national, ethnic, racial, religious, or political group', as such, before listing the acts and therefore modifies the exhaustive list of acts into a non-exhaustive list (Bergsmo

14 Article 5 of the ICTY Statute says, "[t]he International Tribunal shall have the power to prosecute persons responsible for the following crimes when committed in armed conflict, whether international or internal in character, and directed against any civilian population: (a) murder; (b) extermination; (c) enslavement; (d) deportation; (e) imprisonment; (f) torture; (g) rape; (h) persecutions on political, racial and religious grounds; (i) other inhumane acts."

15 See for example, Sec. 5 of United Nations Transitional Administration in East Timor On the Establishment of Panels with Exclusive Jurisdiction Over Serious Criminal Offences, 6 June 2000, UN Doc. UNTAET/Reg/2000/15; Article 2. of the Statute of the Special Court for Sierra Leone, 16 January 2002, 2178 UNTS 138, and Article 5 of the Extraordinary Chambers in the Courts of Cambodia for the Prosecution of Crimes Committed During the Period of Democratic Kampuchea, 27 October 2004.

16 Article 4(2) of ICTY Statute says, "[g]enocide means any of the following acts committed with intent to destroy, in whole or in part, a national, ethnical, racial or religious group, as such: killing members of the group; (b) causing serious bodily or mental harm to members of the group; (c) deliberately inflicting on the group conditions of life calculated to bring about its physical destruction in whole or in part; (d) imposing measures intended to prevent births within the group; (e) forcibly transferring children of the group to another group." Article 6 of the Rome Statute says, "[f]or the purpose of this Statute, 'genocide' means any of the following acts committed with intent to destroy, in whole or in part, a national, ethnical, racial or religious group, as such: (a) Killing members of the group; (b) Causing serious bodily or mental harm to members of the group; (c) Deliberately inflicting on the group conditions of life calculated to bring about its physical destruction in whole or in part; (d) Imposing measures intended to prevent births within the group; (e) Forcibly transferring children of the group to another group." Article 2(2) of ICTR Statute says, "Ig]enocide means any of the following acts committed with intent to destroy, in whole or in part, a national, ethnical, racial or religious group, as such: (a) Killing members of the group; (b) Causing serious bodily or mental harm to members of the group; (c) Deliberately inflicting on the group conditions of life calculated to bring about its physical destruction in whole or in part; (d) Imposing measures intended to prevent births within the group; (e) Forcibly transferring children of the group to another group. 
and Novic 2011, p. 507; Linton 2010, p. 246). This mix-up of words was probably an unintended mistake by the drafters of the ICT Act 1973 (Linton 2010, p. 245). In this case, the consequences of this mix-up are significant. On the one hand, given that the list of acts is non-exhaustive, the crime of genocide can be committed through other acts than those listed. On the other hand, this drafting mistake also deteriorates the intent prerequisite because the group does not have to be attacked 'as such.' The element 'as such' creates the requirement that the accused must act with the intent to destroy the respective group in its quality as that group (O'Keefe 2015, p. 80). The ICTR case law found that the element 'as such' clarifies the specific intent and serves to draw the line between mass murder and genocide (Prosecutor v. Niyitegeka 2004, para. 53). However, the ICTB did not deal with these legal problems but merely disregarded the discrepancies and argued in many cases by regarding all pieces of evidence that the definition of genocide in the ICT Act 1973 conformed to the definition in the Rome Statute (Chief Prosecutor v. Abul Kalam Azad, para. 156), while the meaning of the same crime in the Rome Statute ${ }^{17}$ has not added 'political groups' as one of the protected groups. Therefore, it is inferred from the above discussion that the ICTB has errors to define crimes against humanity and genocide as per customary law requirements in 1971-the material time of the commission of the offense and 2010- the time of the prosecution of the alleged crimes before the Tribunal in question.

However, it is questionable whether the issue of 'Bangladesh Tribunal's legal errors in defining crimes against humanity and genocide' is sensitive in the context of Bangladesh and international criminal justice. The issue is sensitive because it needs to be dealt with carefully to avoid domestic and international criminal law discrepancies to improve Bangladesh's legislative system and harmonize it with international criminal law. Then, the issue is highly sensitive in the academia of international criminal law and tribunal, to evaluate the overall performance of the Tribunal that is prosecuting and punishing the perpetrators of international crimes in violation of some fundamental rights (in Bangladeshi law). For example, Article 47A of the Bangladesh Constitution infringes on several fundamental rights of the accused under the ICT Act, including the right to the prohibition of retroactive prosecution. Article 47A of the Constitution reads, "(1) The rights guaranteed under ... Article $35 \ldots$ shall not apply to any person who is convicted for crimes against humanity, genocide, etc." Article 35 (1) of the Constitution says,

"No person shall be convicted of any offence except for violation of a law in force at the time of the commission of the act charged as an offence, nor be subjected to a penalty greater than, or different from, that which might have been inflicted under the law in force at the time of the commission of the offence."

One of the great debates is whether the ICT Act is unconstitutional since it has excluded some fundamental constitutional rights of Bangladeshi citizens who had been found guilty under the ICT Act. The simple reading of the above provisions of the constitution suggests that whoever will be indicted in the ICT Act 1973, as amended, will not be able to challenge the validity of the Act even though it violates one of the fundamental rights protected by the Constitution, which is nullum crimen sine lege (no crime without law). Lastly, to examine the legal credibility of the Tribunal to provide international criminal justice to the parties. One of the reasons is the international community welcomed this noble initiative and signified it as one of the first tribunals in South Asia in ending the past impunity for international crimes since the IMT Nuremberg between 1945-1946, and the International Military Tribunal for the Far East (IMTFE) Tokyo between 1946-1948 (Menon 2017, pp. 3-4). Hence, the topic is legally sensitive to provide justice to the parties involved and cherish the rule of the Bangladesh legal system. Once the legal faults of the ICTB have been examined in defining crimes against humanity and genocide, it is the substance of the

17 Article 6 of the Rome Statute says, "[f]or the purpose of this Statute, 'genocide' means any of the following acts committed with intent to destroy, in whole or in part, a national, ethnical, racial or religious group, as such: (a) Killing members of the group; (b) Causing serious bodily or mental harm to members of the group; (c) Deliberately inflicting on the group conditions of life calculated to bring about its physical destruction in whole or in part; (d) Imposing measures intended to prevent births within the group; (e) Forcibly transferring children of the group to another group." 
current discussion to outline the status of international law in the Bangladesh legal system in order to determine the legal obligation of the ICTB in applying treaty and customary international law to define the prosecutable crimes in the Tribunal.

\section{Position of International Law in Bangladesh Legal System}

Before analyzing the legal obligation of Bangladesh in applying treaty and customary international law to define international crimes, it is indispensable to examine the legal status of international laws in the legal system of Bangladesh, to infer whether the treaty and customary international law are directly applied in the domestic legal system of Bangladesh. It is also crucial to scrutinize whether the ICTB is obliged or not to comply with international criminal law principles in the case of any conflicts between domestic and international law or any ambiguities between them. The issue of applying international treaties and customary laws and satisfying the legal obligation of Bangladesh to existing criminal justice by prosecuting and punishing international crimes committed in the 1971 conflict is legally significant as the ICTB is operating in an era when International Criminal Court is functioning well. Therefore, it is lawfully convincing to study the judicial decisions of the Bangladeshi domestic courts in applying and interpreting treaty and customary law that involves international legal matters such as human rights, criminal liability, etc. Similarly, it is essential to analyze whether the perpetrators of crimes against humanity and genocide are prosecuted and punished without establishing and proving their jurisdictional bases under the treaty and customary international laws due to some legal complexities in receiving international laws in the domestic legal system.

\subsection{Treaty Law in Bangladesh and Indirect Application of Unincorporated Treaties}

First, regarding international treaties, Article 145A of the Bangladesh Constitution exclusively determines international treaties' ratification in domestic law. ${ }^{18}$ However, no provision discusses the treaty-making process, including negotiation, signing, and ratification of treaties. These aspects of the treaty-making process need to be understood in light of the other general provisions of the Constitution relating to the exercise of the executive authority of the republic.

Article 55(2) of the Constitution says that subject to and in harmony with the Constitution, the executive power of the republic is to be exercised by or on the consultant of the Prime Minister. Like other executive functions, treaty-making is to be performed in accordance with the provisions of the Constitution. Although treaty-making is an executive function, in exercising this function, the Prime Minister and the Cabinet are to be collectively responsible to the Parliament under Article 55(3) of the Constitution.

Under a dualist system such as that in Bangladesh, a treaty must be incorporated into domestic law to be applicable. As a result, in Bangladesh, treaties cannot be applied straightforward in domestic courts unless they are codified into domestic law. Since many international treaties are not domestically promulgated, inconsistencies between international and domestic laws are apparent (Karim and Theunissen 2011, p. 103). In some domestically decided cases, this issue is highlighted. A domestic court may invoke international law for interpretation and application if there is a need to understand domestic law. In the case of Hussain Muhammad Ershad v. Bangladesh and others, Justice Bimalendu Bikash Roy Chowdhury in the Appellate Division (AD) observed that,

"National courts should not ignore the international obligations which a country undertakes. National courts should draw upon the principles incorporated in the international instruments if the domestic laws are ambiguous or absent." (Hussain Muhammad Ershad v. Bangladesh, para. 70)

As a result, it is now a common law of Bangladeshi court's practices to construe national law in conformity with international law and conventions once there is no discrepancy

18 Article 145A of the Constitution says, [all treaties with foreign countries shall be submitted to the President, who shall cause them to be laid before Parliament: provided that any such treaty connected with national security shall be laid in a secret session of Parliament. 
between them or there is an invalid rule in the municipal law (Babu and Ali 2018, p. 18). Furthermore, this legal decision of the highest court of Bangladesh indicates that though the domestic laws do not amply codify international legal principles, the domestic courts are allowed to adopt the international law principle to encounter any domestic law ambiguities or absences. However, the language of the court does not show that it is an obligation.

At the same time, in the case of Bangladesh and another $v$. Hasina and another, it was held that,

"The courts would not enforce international human rights treaties, even if ratified by Bangladesh unless these were incorporated in municipal laws, but they would have looked into the ICCPR while interpreting the provisions of the Constitution to determine the right to life, liberty, and other rights (Bangladesh and another v. Hasina and another, para. 90)."

However, the above decision is not a sacrosanct rule in the practice of treaty application in Bangladesh. For example, in the ICTB cases, the Tribunal said that being a party to the International Covenant on Civil and Political Rights (ICCPR) 1966 since 2000, Bangladesh is obliged to provide 'an effective judicial remedy' to the victims of a serious violation of human rights in 1971. This obligation is expressly recognized in the following terms,

"The victims of atrocities committed in 1971 within the territory of Bangladesh in violation of customary international law need justice to heal. Bangladesh considers that the right to remedy should also belong to victims of war crimes. The State has an obligation to remedy serious human rights violations. Bangladesh recognizes Article $8^{19}$ of the Universal Declaration of Human Rights and Article 2(3) ${ }^{20}$ of the International Covenant on Civil and Political Rights, which ensure the right to an effective remedy for the violation of human rights." (Chief Prosecutor v. Delowar Hossain Sayeedi, para. 47)

It might be questioned on the judicial remedy because it is possible to argue that a civil remedy also exists, but in the case of Bangladesh, it already clarified that ICTB is vested in practicing the right to a criminal remedy for the victims so, no possibility of any other remedies has existed. At the same time, the ICTB uses the word 'obligation,' so any other legal term to posit 'legal obligation' is unnecessary. Likewise, this finding of the ICTB is questionable as the ICCPR is not incorporated in domestic legislation though it is ratified. Suppose this is considered the treaty obligation of Bangladesh under the principle of ICCPR, to punish those who seriously violated human rights without enacting any legislation. In that case, it is also applicable in other treaties, such as the Genocide Convention and the ICC Statute, without passing any domestic legislation according to these treaties. However, because of the Appellate Division's restrictive position, the ICTB is left with little freedom to apply international law. To date, neither the ICTB nor the Appellate Division has complied with Justice Bimalendu Bikash Roy Chowdhury's suggestion as outlined above (Hussain Muhammad Ershad v. Bangladesh, para. 70). Moreover, the legal ruling of the above ICTB case on the 'state obligation' to punish perpetrators of the 1971 Liberation War under ICCPR opens the room for applying treaty laws without formally incorporating them in the domestic legal system.

As a result, the ICTB provides sufficient grounds for applying international law in the case of domestic laws' deficiencies in defining international crimes duly developed under international treaty laws. However, the silence of the ICT Act 1973, Constitutional provisions on the application of unincorporated treaties, and absence of the strict legal obligatory language of the domestic judicial decisions as discussed above certainly put the question on the applicability of international treaty in the Bangladesh legal system.

19 Article 8 of the Universal Declaration of Human Rights 1948 says, "[e]veryone has the right to an effective remedy by the competent national tribunals for acts violating the fundamental rights granted him by the constitution or by law."

20 Article 2 (3) of the ICCPR says, [e]ach State Party to the present Covenant undertakes: (a) To ensure that any person whose rights or freedoms as herein recognized are violated shall have an effective remedy, notwithstanding that the violation has been committed by persons acting in an official capacity." 
Second, it is required an in-depth legal discussion on whether the ICTB is obliged to solve the jurisdictional irregularities, such as the definition of offenses against humanity, genocide, and any other misconducts under international law, by applying the Genocide Convention and ICC Statute to which Bangladesh is a state party. In the absence of direct domestic statutes and constitutional provisions, this answer is solely depending on the indirect application of "unincorporated treaties" in the domestic legal system, which is one of the methods to receive international law and fulfill the legal obligation of Bangladesh to international law, which is analyzed below about some 'State Practices' of a dualist country. Therefore, it is crucial to examine whether Bangladesh as a dualist country can apply such a process of the other dualist nations in fulfilling its legal obligation to an international treaty.

Though, as an official matter, judicial institutions in dualist States have no authority to apply pacts directly as law, it is not an 'absolute rule' presently. It is surprisingly true that courts in dualist states have developed indirect judicial adherence to "unincorporated treaties," even in the absence of any legal instruction for government bureaucrats to take account of treaty provisions (Van Alstine 2009, pp. 608-12). For instance, In Australia, the High Court, in the case of Teoh (Minister of State for Immigration and Ethnic Affairs v Teoh, para. 353), held that "administrative decision-makers must exercise their statutory discretion in conformity with the Convention on the Rights of the Child, an 'unincorporated treaty."' Because "treaty ratification meant that individuals had a legitimate expectation 'that government would act under the treaty (Rothwell 2009, pp. 146-48)."' Followed by Australia, the Canadian Supreme Court also allowed applying an 'unincorporated treaty' against establishing individual rights (Van Ert 2009, p. 173). In the case, Baker v Canada, the Court of Appeal decided that,

"The principle that an international convention ratified by the executive is of no force or effect within the Canadian legal system until incorporated into domestic law does not survive intact the adoption of a principle of law which permits reference to an unincorporated convention during the process of statutory interpretation." (Baker v. Canada (Minister of Citizenship and Immigration), para. 817)

In the above verdict, the Canadian Supreme Court decided that administrative decisionmakers in Canada, like their Australian complements (a dualist state), must practice their legislative discretion in conformity with the Convention on the Rights of the Child, an unincorporated pact (Van Ert 2009, pp. 194-97). Similarly, the Indian Supreme Court regularly adheres 'unincorporated treaties' to support its interpretation of both legal and constitutional provisions (Jayawickrama 2009, pp. 247, 264; Jolly George Verhese v. Bank of Cochin, para. 913; Transmission Corporation of Andhra Pradesh v. Ch. Prabhakar, para. 336). The Court has also applied treaties to support its progressive development of common law principles (Jayawickrama 2009, pp. 168, 255-56). Lastly, in the United Kingdom, petitioners in many lawsuits have also obtained legal remedies by invoking laws that necessitated administrative decision-makers to exercise their power in conformism with treaty commitments that had not been directly merged into municipal law (Rothwell 2009, pp. 491-92). For example, in the case of Secretary of State for Foreign \& Commonwealth Affairs, the Court held that "the Director of Fisheries of South Georgia and the South Sandwich Islands had not properly carried out his statutory powers, because he failed to take account of relevant (unincorporated)treaty provisions (Secretary of State for Foreign \& Commonwealth Affairs v Quark Fishing Ltd., para. 450)."

This discussion elucidated that the cumulative judicial confidence on unincorporated pacts by judicial bodies in dualist States bridges the traditional gap between monist and dualist States. In all of the above cases, most of the dualist States are indirectly applied the provisions of an unincorporated treaty for two reasons: first, to fulfill a State's legal obligation to a compact, second to establish an individual right which is indispensable to invoke in a situation where domestic law is silent. Therefore, Bangladesh is also obliged to apply an unincorporated treaty in its legal system to legally establish an individual 
right of fair proceeding and due process of the defendant by adequately identifying and establishing international criminality of genocide, and crimes against humanity, obliged by the treaty obligation of the Genocide Convention and the ICC Statute.

\subsection{Customary Law in Bangladesh and Its Applicability into the Domestic Legal System}

First, before analyzing the domestic status of customary international law, it is crucial to outline the general legal culture of customary law in Bangladesh. Since the legal system of Bangladesh shares common law tradition, it is indispensable to trace a historical background on the application of international law through the constitution of Bangladesh. The current Constitution of Bangladesh did not alter the practice regarding international law that succeeded before the independence. It provided for the continued operation of the 'law in force' proximately preceding its commencement. The Bangladesh Constitution provides that "[s]ubject to the provisions of this Constitution all existing laws shall continue to affect but may be amended or repealed by-law made under this Constitution (Bangladesh Constitution 1972, Article 149)." The aim of Article 149 is to uphold the endurance of the pre-existing laws even after the inauguration of the constitution till they are changed or annulled, or revised by a competent authority. The question for contemplation is whether the common law of England continues to be in force in Bangladesh after the commencement of the constitution because of Article 149. This issue needs to be examined in light of Article 152 which defines, "'existing law' as any law in force in any part of the territory of Bangladesh immediately before the commencement of the constitution, whether or not it has been brought into operation." Hence, the expression "law in force" used in Article 149 may be interpreted to include the common law of England, which was adopted as the law of Bangladesh and enforced by judicial decisions before taking effect to the constitution (Rahman and Al-Faruque 1999, p. 33).

The provision of the Bangladesh constitution relates to international legal rule dealing with two main issues: international relations and international treaty. Article 25 deals with certain principles of customary international law as 'fundamental principles' of 'state policy,' which says that,

"The State shall base its international relations on the principles of respect for national sovereignty and equality, non-interference in the internal affairs of other countries, peaceful settlement of international disputes, and respect for international law and the principles enunciated in the United Nations Charter."

The article further states that based on the above philosophies, Bangladesh shall endeavor to abandon the use of force in international relations, uphold the right to self-determination, and support the struggle against imperialism, colonialism, or racialism. This is vibrant that constitutional provisions on international law are normative (Rahman and Al-Faruque 1999 , p. 33), and it is the incarnation of rules of jus cogens. ${ }^{21}$ In a broad sense, it imitates the wish of Bangladesh to be a vigorous member of the international community. The issue strengthens this idea that Article 8(2) of the constitution states that "fundamental principles of state policies shall be fundamental to the governance, shall be applied in the making laws, shall be a guide to the interpretation of the constitution and the other laws of Bangladesh." This Article addresses all three organs of the government; the executive and legislature that make possible the invocation and application of international law and the domestic judicial institutions and other authorities at the request of entities or organizations for interpretation of such international law in the light of the Fundamental Values. The contents of this Article reveal that it is not intended to reflect on the relationship between municipal law and international law or lay down any provision for situating customary international law in the domestic legal system. In the missing of any express constitutional provision regarding the place of customary international law in our legal system, it would

21 Jus cogens means "a peremptory norm of general international law is a norm accepted and recognized by the international community of States as a whole as a norm from which no derogation is permitted and which can be modified only by a subsequent norm of general international law having the same character", see for example, Article 53 of the VCLT 1969. 
be pertinent to focus on judicial decisions of Bangladesh, if any, to clarify whether the courts adopted any particular theoretical or practical approach on this issue.

The higher court challenged the issue of how to apply international law for the first time in the case of Bangladesh v. Unimarine S. A. Panama (para. 252); the court stated that "customary international law is binding on the states and states generally give effect to rules and norms of customary international law." The court cited the rule of immunity of foreign envoys, missions, etc., known as decent cases of international customary law that would be obligatory on states. The query ascended in this case whether foreign-owned private corporations have immunity from detention and seizure. On this point, the court said that "[i]mmunity is available under public international law to persons and properties of classified persons mentioned in the list which is usually filed by foreign missions and international agencies (Bangladesh v. Unimarine S. A. Panama, para. 252)."

In the case of Bangladesh Legal Aid and Services Trust v. Bangladesh, although the Court stated that "the universally recognized prohibition of torture ... is a basic principle of customary international law (Bangladesh Legal Aid and Services Trust v. Bangladesh, paras. 7-9)," by citing several treaty provisions on torture, it eventually decided the case based on domestic law. Lastly, however, in the ICTB case of Molla, the AD says,

"International obligations ... cannot be applicable in the domestic tribunal of the country unless the same is incorporated in the domestic law by legislative action. Therefore ... a citizen of the state cannot, in any event, be subjected to the said international obligations/responsibilities of the state." (Abdul Quader Molla v. Chief Prosecutor, pp. 72-73)

In this case, customary law obligation is considered inapplicable under the ICT Act due to non-incorporation customary law definitions of international crimes in the domestic courts. Even though in the same case, the ICTB adheres to implement Article 2(3) of the ICCPR treaty as discussed above, by saying that "[Bangladesh] state has an obligation to remedy serious human rights violations (Chief Prosecutor v. Abdul Quader Molla, para. 45)," without incorporating the said treaty in the Bangladesh domestic legal system. Hence, an apparent contradiction is frequent to invoke treaty and customary laws related to applying international laws in Bangladesh municipal law.

From the above discussion, it is inferred that there are no constitutional provisions available in the constitution of Bangladesh on the application of customary international law. Though in the Unimarine S. A. Panama case, the court invoked to apply customary international law binding on Bangladesh, in the ICTB case of Molla, customary law is outlawed unless it is incorporated in domestic law by legislative action. Therefore, the cases mentioned above do not reflect any precise position of customary law in the Bangladesh legal system in settling domestic disputes on international law. A clear legal gap is evident in applying international customary law in the domestic legal system of Bangladesh to resolve any issue of international law. Hence, it is indispensable to analyze several constitutional provisions of the other dualist countries and their judicial decisions on treating customary international law in a domestic judicial proceeding. One of the legal rationales is to examine the legal obligation of Bangladesh to adhere to international customary law in prosecuting international crimes in the national courts.

Second, based on the above-mentioned legal gap in applying international customary law into Bangladesh's legal system, it is relevant to discuss that Bangladesh is a dualist state sharing common law tradition, and international law in its legal system stands apart from domestic law. Therefore, international law needs to be domesticated via the legislative process before having any consequence on rights and duties at the municipal level. In the dualist domestic system, the validity of international law is determined by a rule of domestic law authorizing the application of that international norm. However, as outlined above, in the Bangladesh legal system, neither constitution nor any judicial decisions determine the application of customary international law, in settling disputes on international law. Therefore, it is essential to analyze other dualist states' constitutional 
provisions and judicial decisions on the acceptance of international customary law in their judicial settlements.

The argument that customary international law takes effect within municipal law may be inferred either from direct formulations in the constitution or judicial decisions in the various constitutions in the world. For example, the Philippines Constitution 1987 provides, "the Philippines ... adopts the generally accepted principles of international law as part of the law of the nation (Philippines Constitution, Article 2(3))." According to the Philippine Supreme Court, "[ $\mathrm{t}]$ his constitutional provision enunciates ... that the Philippines is bound by generally accepted principles of international law which automatically form part of Philippine law by operation of the Constitution (Agpalo 2006, p. 421; Bayan Muna v. Alberto Romulo, para. 37)." Likewise, Article 25 of the Constitution of Germany 1949 provides that "the general rules of the law of nation are part of federal law. They take precedence against domestic law and directly create rights and duties for persons in the country (Constitution of Germany, Article 25)." In Germany, a court verdict of 1981 demonstrated that the Federal Constitutional Court intended to avoid collisions among international and national law by harmonizing rule of "friendliness to international law"22 by saying that,

"In its jurisdiction, the Federal Constitutional Court has to take particular care to avoid or eliminate as far as possible any violations of international law, which could result from a faulty application or ignorance of norms, of international law by German courts and could bring about the responsibility of the Federal Republic of Germany under international law. In specific cases, this can require an extensive review." 23

It is questionable whether Germany is a dualist state. According to German legal scholars, the requirements of the Basic Law neither approve nor reject the proposal that Germany shares a monist system. However, it has apparent structures tending near monism (Lovric 2006, p. 8). Nevertheless, the Federal Constitutional Court has exposed some propensities toward the dualist model (ibid.). Similarly, though Canada is a dualist state, ${ }^{24}$ it does not require customary international law to be legislated separately to have any effect on rights and obligations at the national level; it is automatically merged with the common law (Van Ert 2019, p. 140). Similarly, Canada's main constitutional document, the Charter of Rights and Freedoms, appears now to be understood on a presumption that it nearly fulfills the minimum conditions of international human rights law, which is one of the indications of applying customary international law without any formal legislative procedure (ibid.).

Similar to Bangladesh, in Australia, no constitutional or statutory provisions are available that legalize how courts ascertain and apply rules of customary international law (Burmester 2004, p. 40). However, current practices of the Australian court propose that specific rules of customary international law need to be accepted as part of the domestic law, but the body of customary international law is not directly unified. For instance, in the case of Nulyarimma, it is held that "genocide is not an offense in Australian domestic law, simply because it is an international crime under customary international law over which state [like Australia] may exercise universal jurisdiction (Nulyarimma v. Thompson, para. 621)." The decision of this case shows that customary international law is applicable in the municipal court of a dualist state such as Australia, without domestic incorporation, especially in the application of international criminal law, which is already prohibited in customary law.

22 This principle of "friendliness to international law" may be derived from the preamble and the Article 9 (2) and 24-26 of Germany Constitution. It includes the duty to give effect to international law in municipal law.

23 BVerfGE (The Federal Constitutional Court) of Germany Case No. 58, 1981, para.11, the original case is written in German language which translated and reproduced in Luzzus Wildbaber and Istepban Breitenmoser, "The Relationship between Customary International Law and Municipal Law in Western European Countries", Max-Planck Institut für ausländisches öffentliches Recht und Völkerrecht 48, (1998): 182.

24 Under a dualist legal system, international law in a state stands apart from national law, and to have any effect on rights and obligations at the national level, international law must be domesticated through legislative process, see in Carolyn A. Dubay, "General Principles of International Law: Monism and Dualism" International Judicial Monitor, Winter, 2014, available at http://www.judicialmonitor.org/archive_winter2014/generalprinciples.html (accessed on 20 September 2021). 
Finally, concerning the UK, though it does not have a written constitution, the reception of customary international laws as part and parcel of the common law has been repeatedly asserted in the judicial decisions from the 18th century onwards. The doctrine of incorporation has become the primary approach in Britain in the sphere of customary international law. It was evidently well-defined by Lord Atkin in Chung Chi Cheung v. The King. He noted that,

"International law has no validity except in so far as its principles are accepted and adopted by our domestic law. The courts acknowledge the existence of a body of rules which nations accept among themselves. On any judicial issue, they seek to ascertain what the relevant rule is and having found it, and they will treat it as incorporated into the domestic law, so far as it is not inconsistent with rules enacted by statutes or finally declared by their tribunals." (Chung Chi Cheung v. The King, para. 264)

In the UK, the acts of the Parliament are contemplated to be similar to customary international law, which is ascertained by one of the leading judgments by Lord Porter in the case of Theophile v. The Solicitor General,

"There is a presumption that Parliament does not assert or assume jurisdiction which goes beyond the limits established by the common consent of nations. On the principles already stated, this presumption must give way before an intention is clearly expressed [ ... . ]. Statutes are to be interpreted, provided that their language admits, so as not to be inconsistent with the comity of nations." (Theophile v. The Solicitor General, para. 195)

The above decision clearly shows that it is part of the public policy of England that its courts should give effect to visibly recognized rules of international law, which means customary international law is a portion of the law of England. It is adhered to by the judicial institutions as a general rule of international law. Since the acts of the Parliament are not to legislate some laws repugnant to civilized nations, there is no scope of inconsistency between domestic law, and international customary law is less obviously raised.

From the above in-depth discussion on the rank of customary international law in various dualist states' constitutions and judicial decisions, it is obvious to conclude that Bangladesh has failed adequately to apply customary international law in its domestic settlement of issues concerning international law. While all of the state as mentioned above practices from the Philippines, Germany, Canada, Australia, and the UK have demonstrated that they, directly and indirectly, have applied customary international law in the domestic judicial decision by placing a higher position over municipal law, Bangladesh has not only failed to recognize customary international law in the domestic proceeding but also demonstrated an apparent legal weakness in identifying the status of customary international law in its constitution.

Customs regularly play a pretty significant role, which is stated to be by the domestic courts, in the fields of international law which have not yet been promulgated as law such as international criminal liability (Economides 1993, p. 22). Therefore, a state must invoke customary international law in establishing international criminal liability rather than simply ignoring its application. The excuse of non-incorporation of customary international law in the domestic court as invoked by the AD of Bangladesh in the ICTB Molla case (Abdul Quader Molla v. Chief Prosecutor, pp. 72-73) does not fulfill the legal obligation of Bangladesh under customary international laws, which is practiced by more than 196 States those are presently contacting parties to the Geneva Conventions 1949. At the same time, the constitutional ambiguities to rank customary international law in Bangladesh is also not a good practice as a dualist state because, in many dualist states, customary law is placed higher position than municipal laws directly and indirectly as outlined above. Therefore, Bangladesh is legally obliged to apply customary law in defining crimes against humanity and genocide before prosecuting them in its domestic court. 
Lastly, another crucial issue is the domestic incorporation of customary international law, as the ICTB, which is impossible because such a process would not have any reality. The government would then be under a duty to explicitly sanction all changes, alterations, and new constructions of international law customs and principles. Thus, a scrutiny of all queries about international law (e.g., nationalization of investments, environment, the law of the sea and space; responsibility, immunities, criminal liabilities, etc.) would be desired at least once a year, surveyed by an apprise of the corresponding customary law (Wildbaber and Breitenmoser 1998, p. 182). In such domestic incorporation of customary international law, it will be difficult for the legislature of the specific country, and no secretarial body would ever be capable of undertaking such complications from time to time in order to promulgate the latest customary law into municipal law.

As a result, States have to incorporate the rules of customary international law into their legal system with the help of the wide-ranging formula "international law is part of the law of the land," which means international law would be part of the domestic law automatically without any formulation it into municipal law (ibid.). Or, Even, States can apply customary international law without any specific norm alteration between monism and dualism (ibid.). The principle of straight applicability of customary international law is thus commonly documented in the direction and exercise of many Western countries such as Italy, France, Austria, Greece, and Portugal have due to the explicit reference to adhere customary international law in their constitutions ibid., pp. 183, 185, 187, 189 and 191). Another example of direct application of customary international law is States with a dualist legal system, as analyzed above. Then, regarding applying customary international law, Western European States use a similar rudimentary pattern as the common law countries, where the famous formula "international law is part of the law of the land" has been the law since the 18th century (O'connell 1970, p. 44). In both legal systems, "all such rules of customary International Law as are either universally recognized or have at any rate received the assent of (the states) are per se part of the law of the land (Oppenheim and Lauterpacht 1955, p. 39)." Therefore, Bangladesh's reluctance to apply customary international law is not simply justified by referring to the current state practices of the dualist country in the different parts of the world. As a dualist country, Bangladesh needs to apply international criminal law standards in defining international crimes of genocide and crimes against humanity that are acknowledged as 'jus cogens' crimes in international law. As a dualist state, Bangladesh is also obliged to apply customary international law in prosecuting and punishing international crimes domestically due to widespread invocation of customary rules by current state practices in the international arena and the customary law obligation of Bangladesh to the Genocide Convention and ICC Statute.

\section{Treaty Obligation of Bangladesh in Prosecuting International Crimes}

In the first part of the previous discussion, I focus on the indirect application of 'unincorporated treaties' into Bangladesh's legal system to bridge the legal gap in prosecuting international crimes. However, it is not adequate to understand the legal obligation of Bangladesh to specific treaties such as Genocide Convention 1948, the ICC Statute 1998. Therefore, it is essential to examine specific treaty obligations vested on Bangladesh as a state party to it. For the basis of international treaty law, Bangladesh has signed and ratified many multilateral treaties and is also a party to many bilateral treaties. According to the United Nations Treaty Series, Bangladesh has signed 817 treaties (United Nations Treaty Series Online, p. 4). Some major treaties signed by Bangladesh are human and labor rights, international trade, environmental issues, the law of the sea, international criminal law, ${ }^{25}$ investment, and double taxation. However, not all of these treaties are incorporated into domestic laws. Therefore, it is questionable how the country

25 Bangladesh has ratified Geneva Conventions 1949 on 4 April 1972, see, Treaties, State Parties and Commentaries, ICRC, https://ihldatabases.icrc.org/ applic/ihl/ihl.nsf/vwTreatiesByCountrySelected.xsp?xp_countrySelected=BD\&nv4; Genocide Convention 1948 on 5 October 1998, see ICRC, https: //ihl-databases.icrc.org/applic/ihl/ihl.nsf/States.xsp?xp_viewStates=XPages_NORMStatesParties\&xp_treatySelected=357 (accessed on 25 October 2021); and Rome Statute on 23 March 2010, see https:/ / www.icccpi.int/Pages/item.aspx?name=bangladesh+ratifies+the+rome+statute+of+the+international+ criminal+court\&ln=en\#: :text=On\%2023\%20March\%2C\%202010\%2C\%20the, the \%20Rome\%20Statute\%20to\%20111 (accessed on 24 October 2021). 
settles its domestic disputes in which international laws are directly involved. As outlined above, Bangladesh has ratified the Geneva Conventions 1949, the Genocide Convention 1948, and the ICC Statute 1998 but has yet to incorporate national legislation fully complying with these international treaties. Therefore, it is examined in the following discussion whether Bangladesh has any treaty obligation to the Genocide Convention, particularly in defining genocide as per elements of the 1948 Convention, Rome Statute 1998, as an international crime prosecuted through the ICTB.

It might be questioning why I highlight in discussing the treaty obligation of the offense of genocide in this section? One of the logical answers is that the ICTB is prosecuting crimes against humanity and genocide as international crimes. While genocide is considered a transnational crime, codified and promulgated as the core crime in multilateral treaties such as Genocide Convention 1948, the Rome Statute 1998, crimes against humanity are yet to be codified in multilateral treaties. Therefore, the following analysis focuses on the treaty obligation of Bangladesh to Genocide Convention 1948 and the Rome Statute 1998, at the same time, the legal responsibility of Bangladesh toward defining crimes against humanity analyses in section five of this study.

\subsection{Treaty Obligation to Genocide Convention 1948}

A treaty obligation is conferred by the Genocide Convention 1948 on Bangladesh as a contracting party to it. Regarding the treaty obligation of a state party to the Genocide Convention is self-evident. For example, Article 5 of the Genocide Convention 1948 is an ordinary machinery provision that requires the amalgamation of the Convention's obligations into municipal law, which says,

"The Contracting Parties undertake to enact, in accordance with their respective Constitutions, the necessary legislation to give effect to the provisions of the present Convention, and, in particular, to provide effective penalties for persons guilty of genocide or any of the other acts enumerated in Article 3."

It is characteristic of many other criminal law treaties ${ }^{26}$ in a decentralized international legal order, in which national legal systems provide the primary means for implementing obligations that relate chiefly to the protection of individuals rather than to the regulation of relations between states (Saul 2009, p. 59). Since the Genocide Convention did not establish any international mechanisms for supervising, implementing, or enforcing its obligations, it is obliged under Article 5 to enact domestic legislation. It assumes central importance in giving effect to the Convention and its aspiration to prevent and punish genocide.

In approaching the meaning of Article 5, it is 'self-evident' that the provision is clearly expressed in the language of obligation rather than framed as a mere objective or encouragement. As the ICJ observed in its judgment in the case concerning the Application of the Convention on the Prevention and Punishment of the Crime of Genocide (2007 Judgment), in respect of the identical term 'undertake' in Article 1 (with the same term used in Article 5) that,

"The ordinary meaning of the word 'undertake' is to give a formal promise, to bind or engage oneself, to give a pledge or promise, to agree, to accept an obligation. It is a word regularly used in treaties setting out the obligations of the Contracting Parties." (Bosnia and Herzegovina v. Serbia and Montenegro, p. 162)

In that decision, the ICJ further confirmed that the breach of the obligation under Article 5 and related provisions attracts state responsibility, as a step in rejecting an argument that the Convention concerns only the criminal liability of individuals but does not engage state responsibility. The ICJ accordingly said that,

26 See for example, Slavery Convention 1926, 60 LNTS 253, Article. 6; International Convention for the Suppression of the White Slave Traffic 1910, 7 Martens NR (3d) 252, Article. 3; Convention against Torture and Other Cruel, Inhuman or Degrading Treatment or Punishment 1984, 1465 UNTS 85 , Article. 4(1); Fourth Geneva Convention Relative to the Protection of Civilian Persons in Time of War 1949, 75 UNTS 287, Article. 146. 
"[P]rovisions of the Convention do impose obligations on States in respect of which they may, in the event of a breach, incur responsibility. Articles 5, 6, and 7 requiring legislation, in particular providing effective penalties for persons guilty of genocide and the other acts enumerated in Article 3, and for the prosecution and extradition of alleged offenders are plainly among them." (ibid., p. 59)

Based on the above ruling of the ICJ, the obligation in Article 5 to give domestic effect to the Convention is an essential means of achieving the Convention's purpose in universally suppressing genocide.

The scope of the obligations under Article 5 necessarily derives from the reference to, and dependence on, 'the provisions' of the Convention. At its broadest measure, national legislation could be regarded as 'necessary' to prevent and punish genocide (Article 1); to define the crime and its extended forms (Articles 2 and 3); to make punishable any perpetrator regardless of official status (Article 4); to provide for trial by a competent tribunal 'of the State in the territory of which the act was committed.' One of the vital importance is enactment into domestic law of the definition of genocide under Article 2 (Jessberger 2009, pp. 89-90). Therefore, the incorporation and penalization of genocide as a new international crime indeed center on consensus on its core content, as determined in the treaty negotiation process leading to the Convention, and in light of any subsequent state practice interpreting and applying the definition of genocide (Saul 2009, pp. 63-64). It is crucial to criminalize the acts of genocide as enshrined by the Convention 1948 .

Though treaties in general often allow states considerable discretion in adapting treaty obligations into domestic law, in recognition of the variability of national legal orders and differences in modes of incorporation and legal method, there is less option for variation in implementing international criminal law treaties (ibid., p. 64), for which enactment of a shared and relatively closed or absolute definition of a crime is required. Furthermore, contrasting to human rights law, ${ }^{27}$ refugee law, ${ }^{28}$ or transnational anti-terrorism law (Saul 2006, pp. 130-90), no 'regional' genocide instruments might endorse or encourage localized deviation from the core international definition of genocide. Equally, since the crime of genocide is a creation of international law which did not pre-exist in national law before 1948, unlike, for instance, some international crimes with national origins such as piracy, slavery, or certain war crimes (Saul 2006, p. 64), Article 5 arose against the background of a relatively clean account on which variable national manifestations of genocide were not already written or in need of amendment.

From the above analysis, it might be expected that domestic legislation incorporating the definition of genocide would follow exactly the same meaning as enshrined by the 1948 Convention. This legal trend is confirmed by recent international legal scholars (Schabas 2000, pp. 346-53; Quigley 2006, chp. 3) and articulated in many state practices. ${ }^{29}$ Hence, defining genocide more narrowly in national law than under the Convention would sum to a breach of the obligation under Article 5 to fully affect the Convention (Saul 2006, p. 65). At the same time, defining genocide more generally in municipal law may incorrectly stigmatize slighter demeanor as genocide and go beyond the global community's core policy agreement on what is wrongful about genocide.

27 See for example, the European Convention for the Protection of Human Rights and Fundamental Freedoms 1950, ETS No. 5; American Convention on Human Rights 1969, 1144 UNTS 123; African Charter on Human and Peoples' Rights 1981, 21 ILM 58.

28 See for example, the Convention Governing the Specific Aspects of Refugee Problems in Africa 1969, 1001 UNTS 45; Cartagena Declaration on Refugees 1984, UNHCR Regional Refugee Instruments, available at https://www.refworld.org/docid/3ae6b36ec.html (accessed on 20 September 2021); Annual Report of the Inter-American Commission on Human Rights 1984-1985. OAS Doc. OEA/Ser.L/V/II.66/doc.10, rev 1, (1 October 1985). https://www.cidh.oas.org/annualrep/84.85eng/toc.htm (accessed on 22 September 2021).

29 See for the recent state practices on the strict application of Genocide Convention in defining offense of genocide: Austrian Penal Code 1974, Article 321; Bulgarian Penal Code 1968, Article 416; Czech Republic Penal Code 1961, Article 259; Hungarian Penal Code 1978, Article 137; Italian Genocide Act 1967; Netherlands Genocide Convention Application Act 1964; Portuguese Decree Law Number 48/95 and Penal Code 1995, Article 239; Romanian Penal Code 1969, Article 357; Slovenian Penal Code 1994, Article 373; Spanish Penal Code 1996, Article 607; and Swedish Act on Criminal Responsibility for Genocide, Crimes against Humanity and War Crimes 2014, Article 1. 


\subsection{Treaty Obligation to the Rome Statute 1998}

It is also relevant to mention that beyond the Genocide Convention, the Rome Statute of the ICC also establishes the Court's jurisdiction over genocide. Its definition of the crime is 'essentially a copy' of that in the Genocide Convention (Schabas 2001, p. 31). At the same time, the ICC Statute does not necessitate States to pass a law to accomplish the substantive criminal law of the ICC into national law (Werle 2005, pp. 74-75), and there is no enactment provision equal to Article 5 of the Genocide Convention. However, under the 'complementarity principle' on which the ICC is premised ${ }^{30}$ does presuppose "a general consonance between the substantive law of the ICC and national legal systems," which is reasoned by international criminal law scholars (Saul 2006, p. 82). The ICC Statute thus assists in providing "a source of norms and legal standards that would provide states the basis to effectively investigate and prosecute the most serious crimes under international law themselves (Werle 2005, p. 75)." Therefore, some states, such as Australia (Criminal Code Act 1995 (Commonwealth of Australia)), Section 268(3), (7), and New Zealand (Crimes and International Criminal Court Act (New Zealand) 2000, Section 9), have criminalized genocide for the first time in domestic law based on the ICC Statute rather than the Genocide Convention. While the 'Elements of Crimes' are designed to 'assist the ICC in the interpretation and application' of Statute crimes (Jessberger 2009, p. 87), and states are not required to implement the elements into domestic law, they have, however, influenced national incorporation of genocide. Over time, the essentials of crimes may inspire more harmonization and uniformity in methods to the definition of genocide in federal law, 'tacitly' assisting to form the method in which States obey their obligations under Article 5 of the 1948 Convention (Saul 2006, p. 83). Therefore, it is also identical for Bangladesh to harmonize the elements of crimes of genocide in the national law, under the ICC Statute, Article 6.

Lastly, genocide is considered the 'crime of crimes' in international law (Schabas 2000, pp. 346-53; Prosecutor v. Kambanda, para. 16). Therefore, being at the top of transnational crime in degrees of legal brutality and moral evil, over-broadening the notion jeopardies weakening or corroding the semantic and normative consequence of the crime (Saul 2006, p. 65). Consequently, it might have adverse significances for nourishing a continuing historical remembrance of 'real' genocide; hypothetically misrepresent state's competency to recognize and equate cases of genocide contrary to other forms types of lesser, or qualitatively dissimilar, mass ferocity; diminish the experiences of sufferers of 'real' genocide, and destabilize the efficiency of efforts to stop and prevent genocide a universally understood crime (ibid.). Therefore, it is clarified from the above-detailed analysis on the state's obligation to the international criminal law treaty (Genocide Convention and ICC Statute) that Bangladesh is not obliged to broaden the definition of genocide by addition of 'political group' as one of the protected groups which are omitted in the 1948 Genocide Convention, and ICC Statute 1998. It is somewhat unclear, provided that the groups protected under the Convention are victimized because of their precise characteristics and not for any illogical motives. Therefore, Bangladesh is legally obliged to comply with international criminal law requirements in prosecuting and punishing the offense of genocide, as a transnational crime, through the ICTB.

\section{Customary Law Obligation of Bangladesh}

According to the ICJ Statute, customary international law is one of the primary sources of international law after treaty law (ICJ Statute, Article 38 (1) (b)). Therefore, it is equally vital to infer Bangladesh's legal obligation toward customary international law in prosecuting crimes against humanity. The crimes in question have been considered and prohibited under customary law since World War II. Similar to treaty law, the ICT Act 1973 is silent on the invocation of customary international law in the ICTB in solving any complexities of

30 See Rome Statute of the International Criminal Court 1998, 2187 UNTS 3, Art. 1, says, "[a]n International Criminal Court ('the Court') is hereby established. It shall be a permanent institution and shall have the power to exercise its jurisdiction over persons for the most serious crimes of international concern, as referred to in this Statute, and shall be complementary to national criminal jurisdictions. The jurisdiction and functioning of the Court shall be governed by the provisions of this Statute." 
defining crimes against humanity under international customary international law. However, in many cases, the Tribunal invoked some customary international law rules applied by the UN ad hoc and internationalized tribunals. For instance, in dealing with the issue of retroactivity of criminal law, the Tribunal has decided in many cases that,

"There should be no ambiguity that even under retrospective legislation [the ICT Act 1973] initiation to prosecute crimes against humanity, genocide, and system crimes committed in violation of customary international law is fairly permitted. It is to be noted that the ICTY, ICTR, and SCSL, the judicial bodies backed by the UN have been constituted under their respective retrospective Statutes." (Chief Prosecutor v. Abul Kalam Azad, para. 14; Chief Prosecutor v. Delowar Hossain Sayeedi, para. 52)

The above legal ruling of the ICTB indicates that the Tribunal has adhered to international standard rules invoked by the other International Criminal Tribunals (ICTs) as mentioned above in applying the nullum crimen sine lege (no crimes without law ${ }^{31}$ ) principle in prosecuting the perpetrators of heinous crimes committed in the 1971 Bangladeshi conflict. However, the Tribunal omitted to apply customary law elements of crimes against humanity in the proceeding (Molla v. Chief Prosecutor, p. 127). At the same time, the Tribunal also reiterates by saying that it is an obligation to bring the perpetrators of atrocities and system crimes (crimes against humanity and genocide) into the process of justice. For example, in the case of Molla, the Tribunal invokes,

"It is settled that the 'jus cogens' principle refers to peremptory principles or norms from which no derogatory is permitted, and which may therefore operate a treaty or an agreement to the extent of inconsistency with any such principles or norms. We are thus inclined to pen our convincing view that the obligation imposed on the state by ... the Act of 1973 is indispensable and inescapable, and as such, the 'tripartite agreement' which is merely an 'executive act' cannot liberate the state from the responsibility to bring the perpetrators of atrocities and system crimes into the process of justice." (Chief Prosecutor v. Abdul Quader Molla, para. 106)

It is elucidated from this legal reasoning that it is the legal obligation of Bangladesh to prosecute and punish the perpetrators of crimes against humanity and genocide, which is considered under 'jus cogens' norms. However, throughout the jurisprudence of the ICTB, it is not analyzed whether crimes against humanity gained the status of jus cogens in international penal law, to which a derogation is not permitted. Therefore, from both of the above-mentioned legal decisions of the Tribunal in question, it is indispensable to examine whether crimes against humanity are prohibited as jus cogens crimes in international criminal law. Is it an obligation to prosecute and punish the same crimes under customary international law by a State?

\subsection{Evaluation of Crimes against Humanity as the 'Jus Cogens' Crimes}

The first issue is to examine whether crimes against humanity are regarded as 'jus cogens' crimes in international law. Before analyzing whether crimes against humanity have attained the status of 'jus cogens' prohibition, it is important to outline the emergence of the same notion in international law. The notion of 'jus cogens' found its way into positive international law through the Vienna Convention on the Law of Treaties (VCLT)1969, which determines that,

"A treaty is void if, at the time of its conclusion, it conflicts with a peremptory norm of general international law. For the purposes of the present Convention, a peremptory norm of general international law is a norm accepted and recognized by the international community of States as a whole as a norm from which no

31 Nullum crimen sine lege means prohibition of penalizing certain conducts committed by the perpetrators before the enforcement of such conduct as a law banning such demeanor as an offense, in domestic and international law. 
derogation is permitted and which can be modified only by a subsequent norm of general international law having the same character." (VCLT 1969, Article 53)

Based on the above provision of the VCLT, Professor Bassiouni concludes that the consequences of 'jus cogens are those obligatory, not of noncompulsory rights; if not, then, 'jus cogens' will not establish a peremptory rule of international law (Bassiouni 1996b, p. 65). Precisely, it is challenging to infer whether crimes against humanity as one of the core international crimes considered to be 'jus cogens' crimes by legal scholars' writing, international law instruments. However, opinions of scholars, interpretations of International Law Commissions on the norm of 'jus cogens,' and decisions of international and national courts are indispensable before concluding whether crimes against humanity have attained the status of 'jus cogens' crimes in international criminal law.

According to Bassiouni, a series of legal analyses reveals that the subsequent international crimes are jus cogens: "aggression, genocide, crimes against humanity, and war crimes (ibid., p. 68)." This view of Bassiouni has an adequate legal basis for concluding that all these crimes are part of jus cogens. ${ }^{32}$ As stated by Bassiouni, further legal justification of 'jus cogens' crimes of genocide, crimes against humanity, and war crimes consist of the following: (1) international pronouncements, to reflect the acknowledgment that these offenses are considered part of general customary law (Ackehurst 1975, p. 1); (2) linguistic importance in preambles or other provisions of treaties pertinent to these offenses that shows these crimes "higher status in international law (Bassiouni 1997, p. 70);" (3) a significant number of countries that have signed treaties connected to these misconducts (ibid.); and (4) the ad hoc international investigations and trials of offenders of these wrongdoings (Bassiouni 1996a, p. 11).

Applying these principles to examine whether the 'jus cogens' status of crimes against humanity confirms is a matter of further discussion. For the first condition, such as international declarations on recognizing that crimes against humanity are deemed part of general customary law. It is established that as the first international initiative to criminalize crimes against humanity, the IMT Charter was affirmed by the General Assembly of the UN on 11 December 1946 (UN General Assembly Resolution 1946, 95(1)). As Dubler and Kalyk (2018, p. 94) comment, within the "principle of international law," stated in the UN General Assembly resolution, the meaning of crimes against humanity is mentioned in Article 6(c) of the IMT Charter can be included. Thus, many international law scholars depend on this resolution to ascertain that no less than after December 1946, Article 6(c) of the IMT Charter entered into international legal norms as a prohibited act (ibid.).

In fulfilling the second condition of Bassiouni, i.e., language in preambles or other provisions of treaties applicable to crimes against humanity, it indicates that these crimes have higher prohibitory status in international law. Since crimes against humanity are codified as the core crimes in the Rome Statute, it is relevant to analyze the preamble and any other provisions of the ICC. The preamble to the Rome Statute speaks directly to the duty to prosecute international crimes. The Fourth to Sixth preambular paragraphs read as follows,

"Affirming that the most serious crimes of concern to the international community as a whole must not go unpunished and that their effective prosecution must be ensured by taking measures at the national level and by enhancing international cooperation,

Determined to put an end to impunity for the perpetrators of these crimes and thus to contribute to the prevention of such crimes,

32 The 1993 International Tribunal for the Former Yugoslavia and the 1994 International Tribunal for Rwanda statutes include the Statute of the International Tribunal for the Former Yugoslavia, U.N. SCOR, 48th Sess., 3217th mtg., at 1, U.N. Doc. S/RES/827 (1993) and the Statute for the International Tribunal for Rwanda, U.N. SCOR, 49th Sess., 3453rd mtg., at 1, U.N. Doc. S/RES/955 (1994), and address Genocide, Crimes Against Humanity, and War Crimes. The 1996 Draft Code of Crimes Against Peace and Security of Mankind includes these three crimes, see Titles and Articles on the Draft Code of Crimes Against Peace and Security of Mankind adopted by the International Law Commission on its Forty-Eighth Session, U.N. GAOR, 51st Sess., U.N. Doc. AICN.4L.532 (1996), revised by U.N. Doc. A/CN.4L.532/Corr.1 and U.N. Doc. A/CN.41.532/Corr.3. 
Recalling that it is the duty of every State to exercise its criminal jurisdiction over those responsible for international crimes (Preamble of the Rome Statute 1998)."

The preamble of the Rome Statute does not create independent treaty obligations for the parties, and treaty obligations are not at issue in the present analysis. The question is how the preamble's language contributes to the recognition of certain international crimes as 'higher status.' Crimes against humanity are indeed considered the core international crimes in Article 7 of the ICC Statute.

In applying the third condition, the large number of states that have ratified treaties related to crimes against humanity is also fulfilled for the same crimes as being 'jus cogens' offense. Recently, more than one hundred twenty-three (123) States ratified the ICC Statute. ${ }^{33}$ Hence Bassiouni contends that,

"The establishment of a permanent international criminal court having inherent jurisdiction over these [core] crimes would be a convincing argument for the proposition that crimes such as genocide, crimes against humanity, and war crimes are part of jus cogens crimes." (Bassiouni 1996b, pp. 73-74)

Regarding the last condition of 'jus cogens' crimes, i.e., the ad hoc international investigations and prosecutions of perpetrators of crimes against humanity, it is one of the established principles that perpetrators of crimes against humanity were prosecuted and punished by the IMT Nuremberg, IMTFA, Tokyo, the UN ad hoc tribunals of the ICTY, ICTR, and hybrid courts in the SCSL, ECCC, and SPSC in East Timor. ${ }^{34}$ Though the conditions mentioned above are just legal arguments of Bassiouni on identifying 'jus cogens' crimes in international law, it has a practical consequence for categorizing crimes against humanity as 'jus cogens' crimes because crimes in question have fulfilled all of the aboveanalyzed requirements to be 'jus cogens' crimes. For example, the argument of Bassiouni legally justifies because crimes against humanity are prohibited under customary law, considered to be the most serious crimes under an international treaty (the Rome Statute), many states have ratified treaty to prosecute and punish the crimes in question, and numerous international, ad hoc, and hybrid tribunals have investigated and prosecuted the perpetrators of crimes against humanity as the core international crimes. As a result, one of the established principles in international criminal law is that crimes against humanity have attained the status of 'jus cogens' crimes beyond a reasonable doubt.

Apart from the above analysis, it is also equally important to examine the latest views of international laws on the status of crimes against humanity as the jus cogens crimes. It is essential to critically analyze whether crimes against humanity are categorized as the 'core crimes' proscribed by 'jus cogens.' In attempting to answer this question, the 1996 ILC's Draft Code of Crimes against the Peace and Security of Mankind could be relevant. The 1996 Draft Code fixed the number of crimes in the final Draft Code to four: "aggression, genocide, war crimes, and crimes against humanity (Kittichaisaree 2018, p. 100)." The ILC had initially intended, in 1983, to include those crimes that it deemed "the most serious international offenses ... determined by reference to a general criterion and also to the relevant conventions and declarations on the subject," therefore excluding the less grave ones (Thiam 1983, pp. 46-48). However, by 1996, instead of the gravity of the criminal demeanor or its consequences, the ILC had opted for tradition and the Nuremberg legacy as the criteria for the crimes' definition (Kittichaisaree 2018, p. 101). Accordingly, the provisional summary records of the 2379th Meeting to the 2386th Meeting of the ILC in 1995 indicate that a majority of the ILC members favorably accept the four categories of the

33 See International Criminal Court, https:/ / asp.icccpi.int/en_menus/asp/states\%20parties/pages/the\%20states \%20parties\%20to\%20the\%20rome\% 20statute.aspx\#: : (accessed on 23 October 2021).

34 Crimes against humanity had been recognized as the core crimes in the following international and ad hoc tribunals. See for examples, IMT Nuremberg Charter, Article 6(c); IMTFA Tokyo Charter, Article 5(c). Also defined as an international crime in the Rome Statute of the ICC, Article 7 ; the ICTR Statute, Article 3, and the ICTY Statute, Article 5. The International Residual Mechanism for Criminal Tribunals, continuing the ICTY and ICTR's jurisdiction, and hybrid tribunals such as, ECCC Statute Article 5, and SCSL Statute, Article 2, also have criminalized crimes against humanity. 
crimes as mentioned above (Ortega 1997, pp. 283, 298). Though the ILC does not mention that crimes against humanity are attained the rank of ' jus cogens', indeed they are known as 'jus cogens' offenses due to the seriousness and measure of crimes that shock the conscience of humankind. Even though it is perpetrated within the boundaries of a single state and mainly against citizens of that state, can these offenses be an apprehension of the whole global community (Rome Statute 1998, second recital of the preamble).

Furthermore, the non-derogability of crimes against humanity, originating from their 'jus cogens' position, obliges as a foundation for the argument that the crimes in question might not be exonerated or amnestied (Ahmed and Quayle 2009, p. 7). Bassiouni correctly states, "above all, the characterization of certain crimes as 'jus cogens' places upon states the obligation ... not to grant impunity to the violators of such crimes (Bassiouni 1996b, p. 66)." Therefore, by including crimes against humanity as one of the listed crimes in the 1996 ILC's Draft Code of Crimes against the Peace and Security of Mankind, it is legally justified to strengthen the contention that crimes against humanity have 'jus cogens' status in international law.

Furthermore, under the above legal development of the ILC, some legal interpretations of the scholars are unavoidable to figure out whether crimes against humanity already attained the position of 'jus cogens.' It is now established legally that the terminology 'core crimes' in international criminal law usually refers to genocide, crimes against humanity, war crimes, and aggression (Peter 1997, pp. 177, 188.). Though 'core crimes' are not categorized as 'jus cogens,' these are offenses that are known as a 'serious breach' to international law and orders and need to be punished by any means. It derives from the post-WW II history and the legacy of the IMT Nuremberg and Tokyo (Broomhall 2001, p. 399; Ratner et al. 2009, p. 14). As stipulated in the 1998 Rome Statute of the ICC (Kittichaisaree 2018, p. 103), the core crimes just mentioned constituting "the most serious crimes of concern to the international community as a whole (Rome Statute 1998, fourth preambular paragraph, Article 5)." This concept of 'core crimes' was a focal point of discussion during the formation of the ICC and the drafting of the ICC Statute (Ferencz 1998, p. 203). Although it is still debatable whether the list of core crimes should be expanded (Coracini 2008, p. 699), the concept of core crimes is firmly ingrained in legal phraseology. It identifies those crimes universally condemned as unacceptable by the international community in contrast with other categories of crimes such as transnational offenses or other treaty-based crimes (Boister 1998, p. 27). The addition of crimes against humanity into the 'core crimes,' undoubtedly reinforces the inference that the crimes in question are categorized as 'jus cogens' crimes due to grave breaches to international human rights and humanitarian law.

Besides the 1996 ILC Draft Code, in 2017, the ILC's Drafting Committee on the topic "Immunities of State officials from foreign criminal jurisdiction" provisionally adopted Draft Article 7 listing "crimes under international law in respect of which immunity ratione materiae shall not apply; namely, the crime of genocide, crimes against humanity, war crimes ... to be understood according to their definition in the treaties enumerated in the annex to the Draft Articles (Kittichaisaree 2018, p. 103)." For the crime of genocide, it is as defined in Article 6 of the Rome Statute of the ICC and Article 2 of the 1948 Genocide Convention, crimes against humanity are those stipulated in Article 7 of the Rome Statute, whereas war crimes are as defined in Article 8(2) of the same Statute (ibid.). The ILC's 2017 initiative on "Immunities of State officials from foreign criminal jurisdiction" sufficiently posits the previous works on theorizing crimes against humanity as a severe breach of international law that indeed shocks the conscience of humanity and cannot go unpunished. Therefore, it is not wrong to infer that crimes against humanity are considered 'jus cogens' crimes according to the view of the ILC.

Additionally, in recent time, the ILC, at its sixty-seventh session in 2015, determined to include the topic 'jus cogens' in its Programme of work and selected Dire Tiadi as Special 
Rapporteur for the topic. ${ }^{35}$ The UNGA then, in its resolution 70/236 of 23 December 2015, took a memo of the result of the Commission to comprise the subject in its programme of work. After a series of meetings between 2016-2018, at its 3504th meeting, on 7 August 2019, the Commission took the decision, according to Articles 16 to 21 of the statute, to convey the "Draft Conclusions on Peremptory Norms of General International Law (jus cogens)" via the Secretary-General, to the authority of States for commentaries and annotations. It requested that such statements and remarks be handed over to the Secretary-General by 1 December 2020. Draft Conclusions 23 on Peremptory Norms of General International Law (jus cogens) says,

"Without prejudice to the existence or subsequent emergence of other peremptory norms of general international law (jus cogens), a ... list of norms that the International Law Commission has previously referred to as having that status is to be found in the annex to the present draft conclusions."

Based on the above draft conclusion, it is crucial to mention the prevention of crimes against humanity is the third rule mentioned in the extension. Similarly, the fourth paragraph of the preamble to the 2019 Draft Articles on Crimes against Humanity recalled that "the prohibition of crimes against humanity is a peremptory norm of general international law (jus cogens) (Draft Articles on Crimes Against Humanity 2019, Preamble)." In the explanation to Article 26 of the "Laws on Responsibility of States for Internationally Wrongful Acts," the Commission mentioned not to the ban of crimes against humanity distinctly, but to the prohibition of "crimes against humanity and torture (Laws on Responsibility of States for Internationally Wrongful Acts 2001, Article 26 (5))." The prohibitory status of crimes against humanity is mentioned in the Study Group Report on the Fragmentation of International Law as one of the "most frequently cited candidates" for 'jus cogens' norms (Koskenniemi 2006). Therefore, it is clarified that the draft conclusion on the peremptory norm of general international law maintains the status quo of crimes against humanity to be jus cogens crimes. Arguably (that the said draft conclusion is yet to be codified by the ILC), it has demonstrated solid theoretical development that crimes against humanity are considered 'jus cogens' crimes in international law that need to be punished.

However, before concluding whether crimes against humanity are documented as a peremptory norm of general international law, it is indispensable to examine some international and national criminal jurisprudence on the issue at present. The ICTR Appeals Chamber stated in Nyiramasuhuko that in setting up the ICTR, the UN Security Council had the authority to limit the jurisdiction of the ICTR relating to crimes against humanity "subject to respect for peremptory norms of international law (jus cogens) (Prosecutor $\mathrm{v}$ Nyiramasuhuko, paras. 21, 36)." According to the Constitutional Court of South Africa, a State's obligation to stop impunity is chiefly apparent concerning the norms, such as the proscription on torture and crimes against humanity that are broadly regarded "peremptory and therefore non-derogable (National Commissioner of the South African Police Service v. the Southern African Human Rights Litigation Centre and Others, para. 4)." The Supreme Court of Argentina considered that peremptory norms related to crimes against humanity, and war crimes appeared from rules of international customary law already effective (Arancibia Clavel, Enrique Lautaro s/ homicidio calificado y asociación ilícita y otros, para. 28). It means crimes against humanity have already attained the rank of the peremptory norm in international law. Likewise, in one of the High Court cases from Kenya, the court has pronounced judgment that the "duty to prosecute international crimes" is a peremptory norm of general international law (jus cogens) (The Kenya Section of the International Commission of Jurists v. the Attorney-General and Others, p. 14). Of course, crimes against humanity are considered to be the core international crimes, as discussed above.

35 International Law Commission's 3257th Meeting of the UN General Assembly. Official Records of the General Assembly, Seventieth Session, Supplement No. 10 A/70/10, 27 May 2015, para. 286. The topic had been included in the long-term Programme of work of the Commission during its sixty-sixth session (2014), on the basis of the proposal contained in the annex to the report of the Commission in its Sixty-ninth Session. Official Records of the General Assembly, Sixty-ninth Session, Supplement No. 10 (A/69/10), para. 23. 
Therefore, from the above-detailed analysis on the jus cogens rank of crimes against humanity, it is inferred that it is absolutely ascertained beyond reasonable doubt that crimes against humanity are categorized as jus cogens crimes due to widespread prohibitions of such crimes from IMT Nuremberg, IMTFE Tokyo, the UN ad hoc tribunals, hybrid courts to the ICC regime, and continuous prohibition of this crime by the ILC, in its draft codes as discussed above. It is supported by the scholarly writings that interpret that crimes against humanity are included in the core international crimes. At the same time, international and national tribunals indeed explain the 'jus cogens' nature of crimes against humanity. Lastly, the preambular paragraph of the Draft Articles on Crimes against Humanity 2019 strengthens to conclude that crimes against humanity are recognized as 'jus cogens' norm in international law.

\subsection{Customary Law Obligation of Bangladesh to Prosecute Crimes against Humanity}

The second issue is the customary law obligation of prosecuting crimes against humanity. Based on the above analysis, it is proved that crimes against humanity have attained the status of jus cogens norm. Hence, it is questionable whether international criminal law vested any obligation to punish perpetrators of such crimes by a State. As Bassiouni contends,

"International crimes that rise to the level of jus cogens constitute obligatio erga omnes which are non-derogable. Legal obligations which arise from the higher status of such crimes include the duty to prosecute, the non-applicability of statutes of limitations for such crimes, the non-applicability of any immunities up to and including Heads of State, the non-applicability of the defense of 'obedience to superior orders' (save as mitigation of sentence), the universal application of these obligations whether in time of peace or war, their non-derogation under 'states of emergency,' and universal jurisdiction over perpetrators of such crimes." (Bassiouni 1996b, p. 63)

The above legal argument of Bassiouni reveals that crimes against humanity are 'jus cogens' crimes, it obliges State to prosecute without prejudice to the non-applicability of statutes of limitations for such crimes, the non-applicability of any immunities up to and including Heads of State, the non-applicability of the defense of 'obedience to superior orders.'

Then such legal obligation to sue crimes against humanity as 'jus cogens' crime also referred to hybrid court's jurisprudence. In 2004, the Appeals Chamber of the SCSL referred to the specific obligation to prosecute in the following terms: "under international law, states are under a duty to prosecute crimes whose prohibition has the status of jus cogens (Prosecutor v. Gbao, para. 10)." Though the limits of 'jus cogens' crimes are still contested, it is rarely disputed that crimes against humanity fall into this category (Jackson 2007, p. 130). Certainly, the Appeals Chamber's judgment indirectly denotes crimes against humanity, along with genocide, war crimes, and "other serious violations of international humanitarian law (Prosecutor v. Gbao, para. 10)." Even though the holdings of the Special Court are confined to the Court's statutory mandate, its position as an UN-created hybrid tribunal gives it serious weight in assessing developments in international law.

From the discussion, it is inferred that beyond doubt, crimes against humanity attain the status of 'jus cogens' crimes under the recent international law, which is higher in rank than customary international law. Therefore, Bangladesh is obliged to indict crimes against humanity as 'jus cogens' crimes; at the same time, it also needs to apply the definition of crimes against humanity as developed through the practices of various international, ad hoc, hybrids, and domestic criminal tribunals around the world. As a result, it will discharge the legal obligation, which is conferred on Bangladesh, prosecuting and punishing the perpetrators of crimes against humanity as 'jus cogens' crimes.

\section{ICTB's Assessment in Prosecuting Crimes against Humanity and Genocide}

From the above-detailed analysis, it has been clarified that the ICTB as a governmentsponsor criminal tribunal has owed to the bound treaty and customary international law in prosecuting international crimes committed in the 1971 Bangladesh Liberation War. 
Therefore, it is important to outline in this section whether the ICTB has adhered to its legal obligation to prosecute serious international crimes because the Tribunal has started to operate since 2010, not in 1971 when international criminal justice has developed a lot. In the material jurisdiction of the ICTB, crimes against humanity are measured as the prime offense. To date, 41 individual cases have been delivered verdicts by the Tribunal in question, where all of the defendants have been convicted for the commission of crimes against humanity. Nevertheless, the definition of the said crimes repeatedly violates customary international law principles in 1971 and 2010. For example, as outlined above, crimes against humanity required the nexus of an 'international armed conflict' in 1971 as the customary law condition, which means the crimes need to be committed in an armed conflict categorized as an interstate war. This customary law principle was at first enshrined in the IMT Nuremberg Charter Article 6(c). ${ }^{36}$ The exact requirement is also applicable in the ICTB as the said crimes were committed during the international phase of the Bangladesh conflict (Billah 2020, p. 188). However, the ICTB deliberately failed to apply such customary law requirements of crimes against humanity.

Additionally, the Tribunal's vital legal failure in defining crimes against humanity is that it disregards applying the latest criminal law requirement of crimes against humanity. The said offense needs to be committed in a 'widespread and systematic' attack against any civilian population. This condition was developed during the 1990s by the UNadministered ad hoc international criminal tribunals (the ICTY and the ICTR) and is regarded as the customary rule of international law. ${ }^{37}$ As discussed above, the ICC Statute also adopted this emerging principle of customary international law and some other internationalized criminal tribunals, prosecuting crimes against humanity. Therefore, the definition of crimes against humanity in the ICTB does not adhere to the present and past customary law developments, which are indispensable for identifying and differentiating the same crimes from ordinary crimes.

In prosecuting genocide, though the ICTB applies the elements of the definition of genocide as recognized under international law, it broadened the definition of genocide by the addition of 'political group' as one of the protected groups, which was omitted in the 1948 Genocide Convention and ICC Statute 1998. It is somewhat confusing given that the groups protected under the Convention are targeted because of their specific characteristics. As a result, it is considered one of the failures to meet the international law standards imposed by the Genocide Convention on Bangladesh. Then, the jurisprudence of the ICTB reveals an inaccurate application concerning the specific intent of the crime. In most of the cases as analyzed above, the Tribunal did not establish the specific intent.

For example, the accused Chowdhury was indicted for committing genocide (Chief Prosecutor v. Salahuddin Quader Chowdhury, p. 16) and was found guilty of "substantially contributing [sic] the actual commission of the offense of genocide (Chief Prosecutor v. Chowdhury, para. 88)." The Tribunal omitted to examine the specific intent. It stated that the accused acted on religious bitterness against the Hindu minority because his father had been defeated in the National Assembly elections by a young candidate of the AL, and, driven by this grudge, the accused killed five Hindus and injured one seriously (ibid., para. 87). The Tribunal concluded that the accused acted with "intent to destroy, in whole or in part, the members of [the] Hindu religious group, which is genocide (ibid., para. 88)." The defeat in the elections may well have been a motivation for the act. Still, it does not necessarily amount to the specific intent to destroy the group, in whole or in part, as no evidence to destroy 'in the whole' or 'in part' of the Hindu community can

36 Article 6(c) of the IMT Nuremberg Charter 1945 says, "[c]rimes against humanity: namely, murder, extermination, enslave ment, deportation, and other inhumane acts committed against any civilian population, before or during the war, or persecutions on political, racial or religious grounds in execution of or in con nection with any crime within the jurisdiction of the Tribunal, whether or not in violation of the domestic law of the country where perpetrated." See also in Trials of the Major War Criminals. (Trials of the Major War Criminals Before the International Military Tribunal, Nuremberg, 14 November 1945-1 October 1946) 19, 249.

37 See, Statute of the International Tribunal for Rwanda, SC. Res. 955; UN. SCOR 49th Sess., 3217th mtg., UN. Doc. S/Res/955 (8 November 1994); 33 ILM 1598; Report of the Secretary-General Pursuant to Paragraph (2) of Security Council Resolution 808 (1993), UN Doc. S/25704 (1993), para. 48; Prosecutor v. Tadić, Case No. IT-94-1-T, ICTY Opinion and Judgment, 7 May 1997, para. 646. 
be ascertained in the particular case. In many other cases, the Tribunal also missed out on discussing specific intent before proving the acts of genocide, which is a fatal error to prosecute and punish someone for committing genocide as the 'crimes of crime.' Therefore, the overall assessment of the ICTB reveals that it fails to adhere to the above-discussed legal obligation to try and punish the offenders of crimes against humanity and genocide that were committed in violation of the treaty and customary international law in the Bangladesh Liberation War of 1971.

\section{Proposals to Be Implemented}

The above-detailed analysis has elucidated that crimes against humanity are accepted as 'jus cogens' crimes in international law that are rarely contested in customary international law. It is also proved beyond a reasonable doubt that crimes against humanity are categorized as jus cogens crimes due to widespread prohibitions of such crimes from IMT Nuremberg, IMTFE Tokyo, the UN ad hoc tribunals, hybrid courts to the ICC regime. Therefore, in prosecuting and punishing such crimes, any tribunal needs to adhere to customary law elements of crimes against humanity; otherwise, the crimes in question never be segregated from domestic crimes of murder, extermination, torture, etc. Once the prosecuting tribunal omits to apply customary law requirements of crimes against humanity, the legal competency of the tribunal puts serious doubt in ensuring criminal justice to the parties. Bangladesh Tribunal is one of the examples that has been questioned on its credibility and legally failed not applying customary law requirements in proving the guilt of crimes against humanity, as outlined in section two of the study. Recently, the ICC has been functioning well, and the international criminal justice system is well-developed in prosecuting and punishing the perpetrators of heinous crimes committed in any part of the world. Hence, as the results of this study, I propose the following 'Two Proposals' that the ICTB needs to conform to in order to contribute to the development of international criminal justice.

\subsection{Adherence to Customary Law Definitions of Crimes against Humanity}

First, since the ICTB is operating presently, the Tribunal needs to amend the ICT Act 1973 to insert customary law definition of crimes against humanity. The latest development of customary international law in well-defining crimes against humanity can be seen in the ICC, ICTY, ICTR, and hybrid criminal tribunals' Statutes by adding 'widespread and systematic' attacks against any civilian population, the threshold requirement of the crimes in question. In case of any failure, the ICTB does not secure criminal justice to the relevant parties, which is one of the dangerous precedents for the future international community prosecuting and punishing international crimes through the domestic mechanism.

Second, supposing the above amendment to the ICT Act 1973 is not possible. In that case, the Tribunal in question can apply customary law requirements of crimes against humanity in proving the guilt of crimes against humanity in the ICTB cases, developed throughout the jurisprudence of the ICC, ICTY, ICTR, and ad hoc tribunals as analyzed in the relevant section of this study. In the ICTB, crimes against humanity are being prosecuted at present though they were committed in the 1971 Bangladesh Liberation War, 50 years ago. Within this time, many changes have been taking place in the elements of crimes against humanity. Therefore, it is crucial to apply the latest cases law of the international criminal tribunals in defining crimes against humanity to prove international criminality of murder, extermination, and torture etc. it is the legal duty of the prosecuting tribunal to apply customary law prerequisites to honor the 'jus cogens' status of the crimes in question.

Furthermore, crimes against humanity are recognized as heinous crimes in international law because these crimes undermine the very essence of the existence of humanity. Hence, the juristic opinions have described the enormity of these crimes in the following expression, 
"The phrase "crimes against humanity" has acquired enormous resonance in the legal and moral imagina-tions of the post-World War II world. It suggests, in at least two distinct ways, the enormity of those of-fenses. First, the phrase "crimes against humanity" suggests offenses that aggrieve not only the victims and their communities, but all human beings, regardless of their community. Second, the phrase suggests that these offenses cut deep, violating the core humanity that we all share, and that distinguishes us from other natural beings." (Luban 2004, p. 86)

From the above juristic view, it is clear that crimes in question shock the scruples of humanity and permit intercession by the global community exactly as they are not remote random actions of individuals; nonetheless, instead consequence as of a deliberate effort of targeting a civilian people. Therefore, without fulfilling customary law definition, crimes against humanity, the crimes in question cannot be separated from domestic crimes to weigh their gravity in shocking the conscience of humanity. It is one of the fatal errors of any tribunal that is prosecuting international crimes in a domestic or international setting.

\subsection{Implementation of the Provisions of International Law on Genocide}

In the ICTB, the offense of genocide is indicted in many cases as the second category of international crimes after crimes against humanity. In prosecuting and punishing the offenders of genocide as a transnational crime, though Bangladesh has ratified the Genocide Convention 1948 and the ICC Statute 1998, to date, no 'concrete' legislative articles- passing a new law on genocide, and planning any promulgation of the law on prohibiting and punishing crimes of genocide in the near future is yet to be taken by the Government of Bangladesh to implement the provisions of international law on genocide. Therefore, as a result of this research, I recommend the following proposal to execute the provisions of international law on genocide in the domestic legal system to improve the legislative system and harmonize it with international legislation.

First, the ICTB is obliged to pass legislation prohibiting and punishing the crime of genocide at the national level, according to the constitution of Bangladesh. A treaty obligation is conferred by the Genocide Convention 1948 on Bangladesh as a contracting party to it. Regarding the treaty obligation of a state party to the Genocide Convention is self-evident. For example, Article 5 of the Genocide Convention 1948 is an ordinary machinery provision that requires the amalgamation of the Convention's obligations into municipal law, which says,

"The Contracting Parties undertake to enact, in accordance with their respective

Constitutions, the necessary legislation to give effect to the provisions of the

present Convention, and, in particular, to provide effective penalties for persons guilty of genocide or any of the other acts enumerated in Article 3."

It is characteristic of many other criminal law treaties ${ }^{38}$ in a decentralized international legal order. National legal systems provide the primary means for implementing obligations that relate chiefly to protecting individuals rather than regulating relations between states (Saul 2009, p. 59). Since the Genocide Convention did not establish any international mechanisms for supervising, implementing, or enforcing its obligations, it is obliged under Article 5 to enact domestic legislation of Bangladesh, which assumes central importance in giving effect to the Convention and its aspiration to prevent and punish genocide.

In approaching the meaning of Article 5, the provision is clearly expressed in the language of obligation rather than framed as a mere objective or encouragement. As mentioned above, the International Court of Justice observed in its judgment in the case concerning the Application of the Convention on the Prevention and Punishment of the Crime of

38 See for example, Slavery Convention 1926, 60 LNTS 253, Article. 6; International Convention for the Suppression of the White Slave Traffic 1910, 7 Martens NR (3d) 252, Article. 3; Convention against Torture and Other Cruel, Inhuman or Degrading Treatment or Punishment 1984, 1465 UNTS 85, Article. 4(1); Fourth Geneva Convention Relative to the Protection of Civilian Persons in Time of War 1949, 75 UNTS 287, Article. 146. 
Genocide (2007 Judgment), in respect of the identical term 'undertake' in Article 1 (with the same term used in Article 5) that,

"The ordinary meaning of the word 'undertake' is to give a formal promise, to bind or engage oneself, to give a pledge or promise, to agree, to accept an obligation. It is a word regularly used in treaties setting out the obligations of the Contracting Parties." (Bosnia and Herzegovina v. Serbia and Montenegro, p. 162)

Therefore, Bangladesh has a legal duty toward the Genocide Convention of 1948 to implement the provisions of international law on genocide in the domestic legal system to improve the legislative system and harmonize it with international legislation according to Article 5 of the 1948 Convention.

Second, beyond the Genocide Convention, Bangladesh is obliged to enact legislation on genocide because the country has sanctioned the Rome Statute of the ICC that also establishes the Court's jurisdiction over genocide, and its definition of the crime is 'essentially a copy' of that in the Genocide Convention (Schabas 2001, p. 31). In the ICC Statute, there is no enactment provision equal to Article 5 of the Genocide Convention. However, under the 'complementarity principle' on which the ICC is premised, it does presuppose "a general consonance between the substantive law of the ICC and national legal systems (Saul 2006, p. 82)." The ICC Statute thus assists in providing "a source of norms and legal standards that would provide states the basis to effectively investigate and prosecute the most serious crimes under international law themselves (Werle 2005, p. 75)." For example, some states, such as Australia (Criminal Code Act 1995 (Commonwealth of Australia)), Section 268(3),(7), and New Zealand (Crimes and International Criminal Court Act (New Zealand) 2000, Section 9), have criminalized genocide for the first time in domestic law based on the ICC Statute rather than the Genocide Convention. Over time, the essentials of crimes may inspire more harmonization and uniformity in methods to the definition of genocide in federal law, 'tacitly' assisting to form the States' approach to obey their obligations under Article 5 of the 1948 Convention (Saul 2006, p. 83). Therefore, it is also identical for Bangladesh to implement the provisions of international law on genocide to improve the domestic statutory regulations and harmonize it with international legislation conferring to the ICC Statute, Article 6.

There might be a question on whether the domestic legislations of genocide need to be precisely the same as enshrined in the 1948 Convention. From the above analysis in the relevant section, it is expected that domestic legislation incorporating the definition of genocide must follow exactly the same meaning as enshrined by the 1948 Convention. This legal trend is confirmed by recent international legal scholars (Schabas 2000, pp. 346-53; Quigley 2006, chp. 3) and articulated in many state practices. ${ }^{39}$ Hence, defining genocide more narrowly in national law than under the Convention would mean a breach of the obligation under Article 5 to fully affect the Convention (Saul 2006, p. 65). At the same time, defining genocide more generally in municipal law may incorrectly stigmatize slighter demeanor as genocide and go beyond the global community's core policy agreement on what is wrongful about genocide. Therefore, the Bangladesh government is obliged to strictly implement international provisions on genocide to improve the domestic legislative system and blend it with international laws under the Genocide Convention 1948 and the ICC Statute 1998.

\section{Conclusions}

Based on the above discussions, it is inferred that any criminal trials prosecuting and punishing international crimes aim to strengthen the rule of law and emphasize moral values (Aukerman 2002, pp. 72-73). Therefore, any trials at the domestic level can help

39 See for the recent state practices on the strict application of Genocide Convention in defining offense of genocide: Austrian Penal Code 1974, Article 321; Bulgarian Penal Code 1968, Article 416; Czech Republic Penal Code 1961, Article 259; Hungarian Penal Code 1978, Article 137; Italian Genocide Act 1967; Netherlands Genocide Convention Application Act 1964; Portuguese Decree Law Number 48/95 and Penal Code 1995, Article 239; Romanian Penal Code 1969, Article 357; Slovenian Penal Code 1994, Article 373; Spanish Penal Code 1996, Article 607; and Swedish Act on Criminal Responsibility for Genocide, Crimes against Humanity and War Crimes 2014, Article 1. 
reconstruct or enhance the domestic judiciary and underpin its credibility (Kritz 1996, p. 133). However, trials that are alleged as 'victor's justice' will positively not motivate society to accept the moral values reinforced through them (Aukerman 2002, p. 90). It is precisely identical in the case of the ICTB, which is operated by the victorious party in the Bangladesh conflict, the Awami League, and prosecuted and punished accused who belong to one party in the war. Hence, the ultimate legal failure of the ICTB to try and penalize the political opponent of the Bangladesh government without a proper internationally recognized tribunal further weakened the Tribunal's legal competency. Then, it considered the act of victor's justice that has no contribution to the legal scholarship of domestic prosecution of international crimes.

To conclude, the ICT Act is a piece of legislation that significantly affects healing the past wound of the liberation war victims and inspires the new generation of Bangladesh to substitute a society where the rule of law is cherished even after 50 years of the war. The ICTB is pursuing its operation now. At present, as a state party to the Genocide Convention 1948 and the Rome Statute of the ICC 1998, the current Government of Bangladesh fails to take the necessary initiative to draft the ICT Act 1973 for two legal obligations: first, treaty obligation concerning international crimes' prosecution, and secondly obligation to prosecute crimes against humanity and genocide that are accepted as 'jus cogens' crimes under international law, according to international legal definitions of these crimes. As a result, the ICTB does not secure criminal justice to the relevant parties, which is one of the dangerous precedents with no legal significance to international criminal justice for the future international community prosecuting and punishing international crimes through the domestic mechanism.

Funding: This research has no external funding.

Institutional Review Board Statement: Not related to this research project.

Informed Consent Statement: Not applicable.

Data Availability Statement: This study did not report any data.

Acknowledgments: I would like to extend my heartfelt gratitude to my Ph.D. Supervisor, YAMAGATA Hideo, Department of International Cooperation Studies, Graduate School of International Development, Nagoya University. As an international law scholar, his valuable guidance, insightful comments, and critical feedback on the relevant issues facilitated me to complete this manuscript efficiently.

Conflicts of Interest: The author affirms no conflict of interest.

\section{References}

\section{Primary Sources}

Affirmation of the Principle of International Law Recognized by the Charter of the Nuremberg Tribunal 1946, adopted by the UN General Assembly Resolution 95(I), 11 December ,1946, UN Doc. 95(I)A/236.

Crimes and International Criminal Court Act (New Zealand) 2000.

Criminal Code Act 1995 (Commonwealth of Australia).

Draft Articles on Crimes Against Humanity 2019.

International Crimes Tribunal Act 1973.

International Law Commission. "First Report on the Draft Code of Offences against the Peace and Security of Mankind." Yearbook of International Law Commission, 1983, vol. 2 (Part One), Supp. No. U. N. Doc. A/CN.4/364.

Laws on Responsibility of States for Internationally Wrongful Acts 2001.

Statute of the International Court of Justice 1946.

The Constitution of Bangladesh 1972.

The Constitution of Germany 1949.

The Constitution of Philippines 1987.

The Vienna Convention on the Law of Treaties 1969.

United Nations Treaty Series Online, (United Nations Treaty Collection). Available online: https://treaties.un.org/Pages/U.N.T.S. Online.aspx?id=3\&clang=_en (accessed on 23 September 2021).

Abdul Quader Molla v Chief Prosecutor, ICTB Criminal Appeal No. 24-25 of 2013, Appeal Judgment, 17 September 2013. 
Application of the Convention on the Prevention and Punishment of the Crime of Genocide (Bosnia and Herzegovina v Serbia and Montenegro), Judgment, ICJ Reports, 26 February 2007.

Arancibia Clavel, Enrique Lautaro s/ homicidio calificado y asociación ilícita y otros, [2004], Case No. 259, Supreme Court of Argentina, Appeal Judgment, 24 August 2004.

Baker v Canada (Minister of Citizenship and Immigration), [1999] 2 SCR 817, Supreme Court of Canada, Appeal Judgment, 19 July 1999.

Bangladesh and another $v$ Hasina and another, [2008] 60 DLR 90, Supreme Court, Appeal Judgment, 8 May 2008.

Bangladesh and others $v$ Sombon Asavhan, [1980] 32 DLR 198, Supreme Court, Appeal Judgment, 10 May 1980.

Bangladesh Italian Marble Works Ltd. v Bangladesh, [2005] 62 DLR 553, Supreme Court, Appeal Judgment, 14 July 2005.

Bangladesh Legal Aid and Services Trust v Bangladesh, [2011] 63 DLR 1, High Court, Appeal Judgment, 2 March 2011.

Bangladesh v Unimarine SA Panama, [1997] 29 DLR 252, Supreme Court, Appeal Judgment, 25 June 1997.

Bayan Muna v Alberto Romulo, [2011], Case No. 159618, Supreme Court of the Philippines, Appeal Judgment, 1 February 2011.

Chief Prosecutor $v$ Abdul Quader Molla, ICTB Case No. 02 of 2013, Trial Judgment, 5 February 2013.

Chief Prosecutor $v$ Abul Kalam Azad, ICTB Case No. 05 of 2012, Trial Judgment, 21 January 2013.

Chief Prosecutor v Delowar Hossain Sayeedi, ICTB Case No 01 of 2011, Trial Judgment 28 February 2013.

Chief Prosecutor v Salauddin Quader Chowdhury, ICTB Case No. 02 of 2011, Trial Judgment, 1 October 2013.

Chung Chi Cheung $v$ The King, [1938] AC 160, Privy Council Decision, 2 December, 1938.

Hussain Muhammad Ershad v Bangladesh, [2001] 21 BLC, Supreme Court, Appeal Judgment, 16 August 2001.

Jolly George Verhese v Bank of Cochin, [1980] 2 SCR 913, Supreme Court of India, Appeal Judgment, 4 February,1980.

Kenya Section of the International Commission of Jurists $v$ the Attorney-General and Others, [2011] eKLR Miscellaneous Criminal Application 685 of 2010, The High Court of Kenya, Appeal Judgment, 28 November 2011.

Minister of State for Immigration and Ethnic Affairs v Teoh, [1995] 128 ALR 353, High Court of Australia, Appeal Judgment, 7 April 1995.

National Commissioner of the South African Police Service v the Southern African Human Rights Litigation Centre and Others, [2014] 12 BCLR 1428, Constitutional Court of South Africa, Judgment of 30 October 2014.

Nulyarimma $v$ Thompson, [1999] 165 ALR 621, Federal Court of Australia, Appeal Judgment, 1 September 1999.

Prosecutor $v$ Gbao, Case No. SCSL-04-15-PT-141, SCSL Appeals Chamber Decision on Preliminary Motion on the Invalidity of the Agreement Between the United Nations and the Government of Sierra Leone on the Establishment of the Special Court, 25 May 2004.

Prosecutor v Kambanda, ICTR, Case No. ICTR 97-23-S, ICTR Trial Chamber Judgment and Sentence, 4 September 1998.

Prosecutor v Niyitegeka, Case No. ICTR-96-14-T, ICTR Appeal Judgment, 9 July 2004.

Prosecutor v Nyiramasuhuko Case No. ICTR-98-42, ICTR Appeal Chamber Judgment, 14 December 2015 paras. $21,36$.

Prosecutor $v$ Tadić, Case No. IT-94-1-T, ICTY Decision on The Defence Motion for Interlocutory Appeal on Jurisdiction, 2 October 1995.

Secretary of State for Foreign \& Commonwealth Affairs v Quark Fishing Ltd., [2002] EWCA Civ 1409, England and Wales Court of Appeal Judgment, 30 October 2002.

Theophile $v$ The Solicitor General, [1950] AC 186, House of Lords, Appeal Judgment, 9 February 1950.

Transmission Corporation of Andhra Pradesh v Ch. Prabhakar, [2004] ILDC 336, Supreme Court of India, Appeal Judgment, 26 May 2004.

\section{Secondary Sources}

Ackehurst, Michael. 1975. Custom as a Source of International Law. British Year Book of International Law 47: 1-53. [CrossRef]

Agpalo, Rupen E. 2006. Public International Law. Manila: Rex Book Store.

Ahmed, Anees, and Merryn Quayle. 2009. Can Genocide, Crimes against Humanity and War Crimes be Pardoned or Amnestied? Amicus Curiae 79: 15-20. Available online: https://sas-space.sas.ac.uk/2563/1/Amicus79_Ahmed\%26Quayle.pdf (accessed on 25 October 2021). [CrossRef]

Aukerman, Miriam J. 2002. Extraordinary Evil, Ordinary Crime: A Framework for Understanding Transitional Justice. Harvard Human Rights Journal 39: 39-99.

Babu, M. Asrafuzzaman, and Aroj Ali. 2018. Status of International Treaty in Bangladesh: Approach of the Supreme Court. Journal of Law and Global Policy 3: 16-20.

Bassiouni, M. Cherif. 1996a. From Versailles to Rwanda: The Need to Establish a Permanent International Criminal Court. Harvard Human Rights Journal 10: 11-62.

Bassiouni, M. Cherif. 1996b. International Crimes: Jus Cogens and Obligatio Erga Omnes. Law and Contemporary Problems 59: 63-74. [CrossRef]

Bassiouni, M. Cherif. 1997. International Criminal Law Conventions and their Penal Provisions. Leiden: BrillNijhoff.

Bergsmo, Morten, and Elisa Novic. 2011. Justice after Decades in Bangladesh: National Trials for International Crimes. Journal of Genocide Research 13: 503-10.

Billah, Maruf. 2020. Non-retroactivity in Prosecuting Crimes against Humanity and International Crimes Tribunal Bangladesh. Journal of Politics and Law 13: 180-95. [CrossRef]

Boister, Neil. 1998. The Exclusion of Treaty Crimes from the Jurisdiction of the Rome Statute of the International Criminal Court. Journal of Armed Conflict Law 3: 27-43.

Broomhall, Bruce. 2001. Towards the Development of an Effective System of Universal Jurisdiction for Crimes Under International Law. New England Law Review 35: 399-420. 
Burmester, Henry. 2004. The determination of customary international law in Australian courts. Non-State Actors and International Law 4: 39-47. [CrossRef]

Coracini, A. Reisinger. 2008. Amended Most Serious Crimes": A New Category of Core Crimes within the Jurisdiction but out of the Reach of the International Criminal Court?". Leiden Journal of International Law 21: 699-718. [CrossRef]

Dubler, Robert, and Matthew Kalyk. 2018. Crimes against Humanity in the 21st Century: Law, Practice and Threats to International Peace and Security. Leiden: BrillNijhoff.

Economides, Constantine. 1993. The Relationship between International and Domestic Law. Venice, Italy: European Commission for Democracy Through Law, Available online: https:/ / www.venice.coe.int/webforms/documents/default.aspx?pdffile=CDLSTD(1993)006-e (accessed on 23 September 2021).

Ferencz, Benjamin. 1998. International Criminal Courts: The Legacy of Nuremberg. Pace International Law Review 10: $203-35$.

Islam, M. Rafiqul. 2019. National Trials of International Crimes in Bangladesh: Transitional Justice as Reflected in Judgments. Leiden: Brill I Nijhoff.

Jackson, Miles M. 2007. The Customary International Law Duty to Prosecute Crimes against Humanity: A New Framework. Tulane Journal of International and Comparative Law 16: 117-57.

Jessberger, Florian. 2009. The Definition and the Elements of the Crime of Genocide. In The UN Genocide Convention: A Commentary. Edited by Paola Gaeta. Oxford: Oxford University Press, pp. 87-110.

Karim, Bianca, and Tirza Theunissen. 2011. Bangladesh. In International Law and Domestic Legal Systems Incorporation, Transformation and Persuasion. Edited by Dinah Shelton. Oxford: Oxford University Press, pp. 99-120.

Kittichaisaree, Kriangsak. 2018. The Obligation to Extradite or Prosecute. Oxford: Oxford University Press.

Koskenniemi, Martti. 2006. Report of the Study Group on Fragmentation of International Law: Difficulties Arising from the Diversification and Expansion of International Law. International Law Commission, 344-45. UN Doc. A/CN.4/L.682, paras. Available online: https://legal.un.org/ilc/documentation/english/a_cn4_1682.pdf (accessed on 25 October 2021).

Kritz, Neil J. 1996. Coming to Terms with Atrocities: A Review of Accountability Mechanisms for Mass Violations of Human Rights. Law \& Contemporary Problems 59: 127-52.

Linton, Suzannah. 2010. Completing the Circle: Accountability for the Crimes of the 1971 Bangladesh War of Liberation. Criminal Law Forum 21: 191-311. [CrossRef]

Lovric, Daniel. 2006. A Constitution Friendly to International Law: Germany and its Völkerrechtsfreundlichkeit. Australian Yearbook of International Law 4: 75-104. [CrossRef]

Luban, David. 2004. A Theory of Crimes against Humanity. Yale Journal of International Law 29: 85-167.

Menon, Pravati. 2017. International Crimes Tribunal in Bangladesh. MPILux Working Paper 11. Luxembourg: Max Planck Institute, pp. 1-19. Available online: https://www.mpi.lu/fileadmin/mpi/medien/research/MPEiPro/IC_Tribunal_in_Bangladesh_lawmpeipro-e3092.pdf (accessed on 22 October 2021).

Jayawickrama, Nihal. 2009. India. In The Role of Domestic Courts in Treaty Enforcement: A Comparative Study. Edited by David Sloss. Cambridge: Cambridge University Press, pp. 243-72.

O'connell, Daniel Patrick. 1970. International Law, 2nd ed. London: Stevens, vol. 1.

O'Keefe, Roger. 2015. International Criminal Law. Oxford: Oxford University Press.

Oppenheim, Lassa, and Hersch Lauterpacht. 1955. International Law. London: Longmans Green \& Co, vol. 1.

Ortega, Martin C. 1997. The ILC Adopts the Draft Code of Crimes against the Peace and Security of Mankind. Max Planck Yearbook of UN Law 1: 283-326. [CrossRef]

Peter, Matthew. 1997. The Proposed International Criminal Court: A Commentary on the Legal and Political Debates regarding Jurisdiction that Threaten the Establishment of an Effective Court. Syracuse Journal of International Law E Commerce $24: 177-97$.

Quigley, John. 2006. The Genocide Convention: An International Law Analysis, 1st ed. London: Routledge.

Rahman, S. Hafizur, and Abdullah Al-Faruque. 1999. Status of International Law under the Constitution of Bangladesh: An Appraisal. Bangladesh Journal of Law 3: 23-46.

Ratner, Steven R, Jason S. Abrams, and James L. Bischoff. 2009. Accountability for Human Rights Atrocities in International Law: Beyond the Nuremberg Legacy, 3rd ed. Oxford: Oxford University Press.

Robertson, Geoffrey. 2015. Report on the International Crimes Tribunal of Bangladesh. International Forum for Democracy and Human Rights. Available online: http://www.barhumanrights.org.uk/wpcontent/uploads/2015/02/REPORT-ON-THEINTERNATIONAL-CRIMES-TRIBUNAL-OFBANGLADESH.pdf (accessed on 25 October 2021).

Rothwell, Donald R. 2009. Australia. In The Role of Domestic Courts in Treaty Enforcement: A Comparative Study. Edited by David Sloss. Cambridge: Cambridge University Press, pp. 120-65.

Saul, Ben. 2006. Defining Terrorism in International Law. Oxford: Oxford University Press.

Saul, Ben. 2009. The Implementation of the Genocide Convention at the National Level. In The UN Genocide Convention: A Commentary. Edited by Paola Gaeta. Oxford: Oxford University Press, pp. 58-83.

Schabas, William A. 2000. Genocide in International Law: The Crime of Crimes. Cambridge: Cambridge University Press.

Schabas, William A. 2001. An Introduction to the International Criminal Court. Cambridge: Cambridge University Press.

Schabas, William A. 2006. The UN International Criminal Tribunals: The Former Yugoslavia, Rwanda and Sierra Leone. Cambridge: Cambridge University Press. 
Thiam, Doudou. 1983. First report on the Draft Code of Offences against the Peace and Security of Mankind. Yearbook of International Law Commission 2: 46-69.

Van Alstine, Michael P. 2009. The Role of Domestic Courts in Treaty Enforcement: Summary and Conclusions. In The Role of Domestic Courts in Treaty Enforcement: A Comparative Study. Edited by David Sloss. Cambridge: Cambridge University Press, pp. 555-614.

Van Ert, Gib. 2009. Canada. In The Role of Domestic Courts in Treaty Enforcement: A Comparative Study. Edited by David Sloss. Cambridge: Cambridge University Press, pp. 166-208.

Van Ert, Gib. 2019. The Domestic Application of International Law in Canada. In The Oxford Handbook of Comparative Foreign Relations Law. Edited by Curtis A. Bradley. Oxford: Oxford University Press, pp. 140-81.

Werle, Gerhard. 2005. Principles of International Criminal Law. The Hague: TMC Asser Press.

Wildbaber, Luzzus, and Stepban Breitenmoser. 1998. The Relationship between Customary International Law and Municipal Law in Western European Countries. Max-Planck Institut für ausländisches öffentliches Recht und Völkerrecht 48: 163-207. 